\title{
Metallomics
}

Cite this: Metallomics, 2013, 5, 597

Received 22nd December 2012, Accepted 7th March 2013

DOI: $10.1039 / c 3 m t 20261 \mathrm{e}$

www.rsc.org/metallomics

\section{The use of X-ray absorption and synchrotron based micro-X-ray fluorescence spectroscopy to investigate anti-cancer metal compounds in vivo and in vitro}

\begin{abstract}
Alfred A. Hummer and Annette Rompel*
X-ray absorption spectroscopy (XAS) and micro-synchrotron based X-ray fluorescence (micro-SXRF) are element specific spectroscopic techniques and have been proven to be valuable tools for the investigation of changes in the chemical environment of metal centres. XAS allows the determination of the oxidation state, the coordination motif of the probed element, the identity and the number of adjacent atoms and the absorberligand distances. It is further applicable to nearly all types of samples independent of their actual physical state (solid, liquid, gaseous) down to $\mu \mathrm{M}$ concentrations. Micro-SXRF can provide information on the distribution and concentration of multiple elements within a sample simultaneously, allowing for the chemical state of several elements within subcellular compartments to be probed. Modern third generation synchrotrons offer the possibility to investigate the majority of the biologically relevant elements. The biological mode of action of metal-based compounds often involves interactions with target and/or transport molecules. The presence of reducing agents may also give rise to changes in the coordination sphere and/or the oxidation state. XAS and micro-SXRF are ideal techniques for investigating these issues. This tutorial review introduces the use of XAS and micro-SXRF techniques into the field of inorganic medicinal chemistry. The results obtained for platinum, ruthenium, gallium, gold and cobalt compounds within the last few years are presented.
\end{abstract}

Institut für Biophysikalische Chemie, Universität Wien, Althanstr. 14, 1090 Wien, Austria. E-mail: annette.rompel@univie.ac.at; Fax: +43-1-4277-9525; Tel: +43-1-4277-52502



Alfred A. Hummer
Alfred A. Hummer obtained his bachelor's and master's degrees in Biotechnology at the University of Natural Resources and Life Sciences (BOKU), Vienna. He joined the Institute of Biophysical Chemistry at the University of Vienna in 2009, where he is currently completing his $P h D$ in Chemistry. The main focus of his work is on the structure and function elucidation of anticancer ruthenium and gallium compounds in biological tissues and in the presence of possible target molecules, applying X-ray absorption and micro-X-ray fluorescence techniques based on synchrotron radiation.

\section{Introduction}

Metal compounds have been used in the treatment of a various number of diseases, but it was in 1965 when Rosenberg et al.

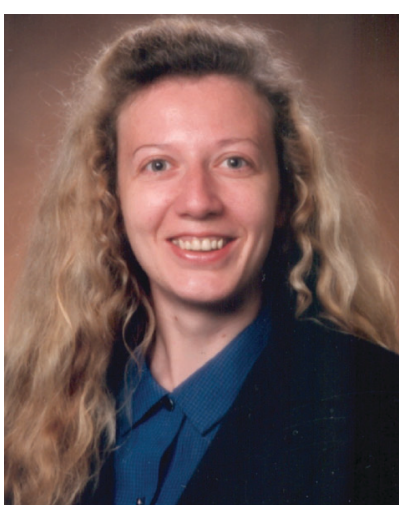

Annette Rompel
Annette Rompel has been the head of the Institute of Biophysical Chemistry at the University of Vienna since 2008, when she joined the Faculty of Chemistry. She studied chemistry at the University of Münster where she received her $P h D$. Besides research at the University of California, Berkeley and the Lawrence Berkeley National Laboratory she was a visiting scientist at RIKEN, The Institute of Physical and Chemical Research, Sendai, Japan and the University of Southern Denmark, Odense. Her main research interests are metal containing enzymes from natural sources and their structure and function elucidation using synchrotron based techniques. 
first encountered the anti-tumoural activity of cisplatin. ${ }^{1}$ Since then intensive research in the field of tumour inhibiting metal complexes has been undertaken. X-ray absorption spectroscopy (XAS) is an important tool for the examination of structurally undefined heterogeneous systems. There are several review articles on the anti-tumoural activity of metal complexes ${ }^{2-6}$ as well as the application of XAS ${ }^{7-14}$ and micro-SXRF ${ }^{15-17}$ in biological systems or bioinorganic chemistry. This review will provide a glimpse into the possibilities, applications and outcomes of these spectroscopic techniques in metal based cancer research.

It focuses on the metal complexes of platinum, gallium, ruthenium, gold and cobalt which were recently investigated using XAS and micro-SXRF, and are promising candidates for use as anti-cancer agents.

The first section of this article will give an overview of XAS and micro-SXRF and their underlying principles. The following sections will discuss the proposed modes of action of compounds comprised of the aforementioned metals and present the latest results of XAS and micro-SXRF investigations and their contributions to the clarification of the in vivo pathways.

\subsection{X-ray absorption spectroscopy in a nutshell}

XAS is a method which probes the core-shell electrons of an atom (1s, 2s or 2 p) by means of X-rays. Corresponding to the energy levels of the core shell electrons of the probed element, the X-rays will be absorbed at distinct energies displayed in a sudden rise in the absorption spectrum. This increase in absorption is called the $\mathrm{X}$-ray absorption edge or edge. According to the energy state of the excited electron the edges are named $\mathrm{K}(1 \mathrm{~s}), \mathrm{L}_{\mathrm{I}}(2 \mathrm{~s})$ and $\mathrm{L}_{\mathrm{II}}$ and $\mathrm{L}_{\mathrm{III}}$ $\left(2 \mathrm{p}_{1 / 2}\right.$ and $\left.2 \mathrm{p}_{3 / 2}\right)$. The sector from 30 electron volt $(\mathrm{eV})$ below and up to $50 \mathrm{eV}$ above the edge is called the X-ray absorption near edge structure (XANES) and the ongoing spectral features are called extended X-ray absorption fine structure (EXAFS). In the XANES regime the electrons are excited into the lowest unoccupied bound state orbitals (LUMO) just above the Fermi energy. In the case of EXAFS the electrons are promoted into higher energy states (the so called continuum), creating a photoelectron and interacting with the surrounding atoms. ${ }^{9}$ The constructive and destructive interactions of the photoelectron with the backscattering from adjacent atoms give rise to the well known oscillations in EXAFS (see Fig. 1). XANES gives important information about the oxidation state, the electronic structure of the absorber-ligand environment and the coordination motif of the excited atom, whereas EXAFS is suitable to determine the absorber-ligand distances and the number and the type of the nearest neighboring atoms (up to about $4 \AA$ ).

The analysis of the absorption spectra, their features and the underlying principles are discussed elsewhere. ${ }^{18-21}$ For further reading introductory books of Bunker, ${ }^{18}$ de Groot and Kotani, ${ }^{22}$ and Stöhr, ${ }^{23}$ and review articles ${ }^{19,24,25}$ covering the underlying principles, applications and analysis of XAS can be recommended. Furthermore, the articles of Rehr and Albers ${ }^{26}$ and Ankudinov et $a .^{27}$ discuss the theoretical models applied to XAS in detail. A historical overview of the development of XAS is given in the reviews of Lytle $^{28}$ and Stumm von Bordwehr. ${ }^{29}$

\subsection{Microprobe synchrotron based X-ray fluorescence}

Micro-synchrotron based X-ray fluorescence (micro-SXRF) or microsynchrotron radiation induced X-ray emission (micro-SRIXE) ${ }^{30}$ uses X-ray beams focused to spot sizes ranging from hundreds of $\mu \mathrm{m}^{2}$ down to the $\mathrm{nm}^{2}$ range. The sample stage is moved in a fixed distance horizontally and vertically relative to the incoming beam to raster the desired sample area. Depending on the beam size and collection time per spot the distribution and concentration profiles of larger sample areas or subcellular structures can be monitored. When collecting SXRF data all elements with lower edge


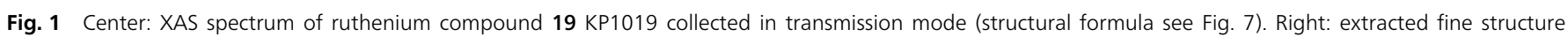
(EXAFS) and Fourier transform (FT) thereof. Left: the normalized XANES spectrum and the normalized derivative $f^{\prime}(\mathrm{x})$. 
energies than the incident one are excited and the corresponding spatial distribution data of these elements are collected at once. Micro-SXRF is applied in anti-cancer research to study the two dimensional distribution and concentration of metals and other biologically important elements, like phosphorus or sulfur, in cell or tissue samples. Thus, the direct assignment of the metal distribution to specific biological functions and targets is possible, e.g. DNA binding or accumulation in membrane regions. To quantify the elements in the tissue or cells the collected spectra and peak intensities must be calibrated against a standard of known composition and concentrations of the elements in question. ${ }^{15,16,31}$

\subsection{Application of XAS in biological systems}

XAS can be applied independently of the actual physical state (solid, liquid, gaseous) and does not require any long range order. It has evolved into a standard measurement technique in the study of amorphous materials and in bioinorganic chemistry. ${ }^{14,24}$ Especially in the investigation of spectroscopically silent metals like $\mathrm{Au}(\mathrm{I}), \mathrm{Zn}$ (II), $\mathrm{Ga}$ (III) and $\mathrm{K}(\mathrm{I}), \mathrm{Ca}(\mathrm{II}), \mathrm{Mg}$ (II) with a full or an empty d-shell it is one of the few techniques which can obtain valuable structural information. ${ }^{32}$ XAS is elemental specific and the elements $\mathrm{Pt}, \mathrm{Ru}, \mathrm{Ga}$, and $\mathrm{Au}$ are not naturally abundant chemical species in biological tissues. This makes XAS an ideal choice for the study of anti-tumoural compounds. ${ }^{33}$

\section{Platinum compounds}

In the last few years the research in the field of Pt(II) complexes focused on cisplatin (1), ${ }^{1}$ carboplatin (2), ${ }^{34}$ oxaliplatin (3), ${ }^{35}$ and nedaplatin (4). ${ }^{36-38}$ These compounds are available commercially and are in clinical use worldwide ( $\mathbf{1}$ cisplatin, $\mathbf{2}$ carboplatin and 3 oxaliplatin, Fig. 2), or at least in one country: 4 nedaplatin (Japan, Fig. 2), ${ }^{36,37}$ heptaplatin (5, Republic of Korea, Fig. 2) (36,37 $^{\text {and }}$ lobaplatin (6, China, Fig. 2). ${ }^{39}$ Today these drugs are mostly used in combined treatment plans. ${ }^{40,41}$

The pharmacological mode of action is supposed to be similar for 1 cisplatin, 2 carboplatin, 3 oxaliplatin and 4 nedaplatin. ${ }^{42}$ The complexes can be seen as pro-drugs activated through hydrolysis, ending in an active diamine-diaquo-platinum complex (diaminocyclohexane-diaquo-platinum for 3 oxaliplatin). ${ }^{42}$ The difference in their cytotoxicity is found to be due to their differing pharmacokinetic behaviour, mainly governed by the velocity of aquation of the leaving ligands chloride ( 1 cisplatin), cyclobutane ( 2 carboplatin), the oxalate group ( 3 oxaliplatin) and the glycolate moiety (4 nedaplatin). ${ }^{39,42}$ The tumour inhibiting Pt(II) complexes are supposed to form adducts with amine groups of proteins, RNA and DNA. Mainly the crosslinking of guanine (N7 position) and adenine residues in DNA is thought to be the major cause of cytotoxicity. The crosslinking occurs within the same strand (intrastrand) and between different strands (interstrand). The bending of the DNA strand prohibits proper DNA transcription and the large number of crosslinks overwhelms the DNA repair mechanisms. ${ }^{43}$ Thus, cells with enhanced DNA repair mechanisms tend to exhibit a resistance to 1 cisplatin. ${ }^{42,43}$ Although DNA is a major target for platinum drugs it is not necessarily the only

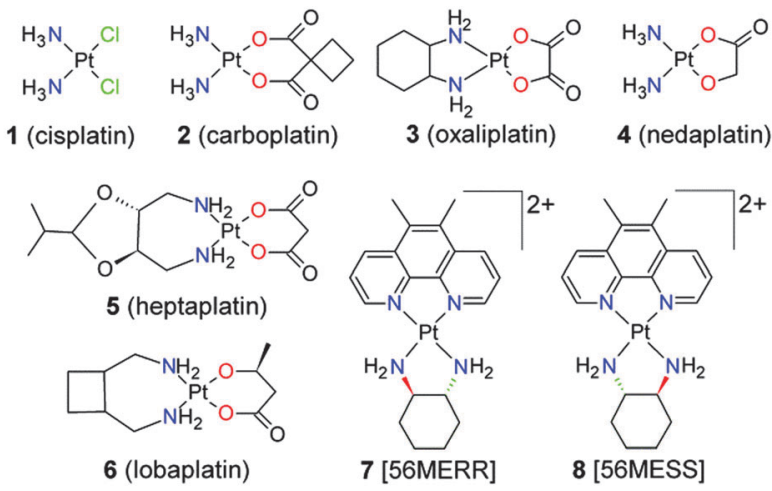

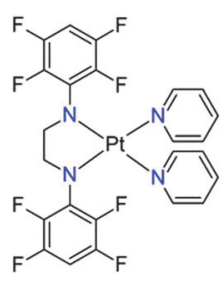

$12(\mathrm{Pt103})$
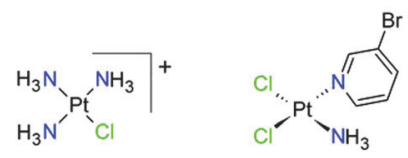

16

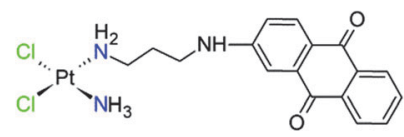

18 (Pt-2C3)
Fig. 2 Top: the most prominent Pt(॥) anti-cancer drugs today: cis-diamminedichloroplatinum(II) (1, cisplatin), cis-diammine(cyclobutane-1,1-dicarboxylate-O, $O^{\prime}$ )platinum(॥) (2, carboplatin), [(1R,2R)-cyclohexane-1,2-diamine](ethanedioato-O, $\left.O^{\prime}\right)$ platinum(॥) (3, oxaliplatin), (diammine[hydroxyacetato(2-)-O, $O^{\prime}$ ]platinum(॥) (4, nedaplatin). Center: [propanedioato(2-)-O,O'][2-(1-methylethyl)-1,3-dioxolane4,5-dimethanamine- $N, N^{\prime}$ ]platinum(॥) (5, heptaplatin), [2-hydroxypropanoato(2-)-O1,O2][1,2-cyclobutanedimethanamine- $\left.N, N^{\prime}\right]$ platinum(॥) (6, lobaplatin), and the intercalators [Pt(5,6-dimethyl-1,10-phenanthroline)(trans-1R,2R-diaminocyclohexane) $]^{2+}(7,[56 \mathrm{MERR}])$, and [Pt(5,6-dimethyl-1,10-phenanthroline)(trans-1S,2Sdiaminocyclohexane)] ${ }^{2+}(\mathbf{8},[56 \mathrm{MESS}])$. Bottom: the Pt(॥) complexes: [trisamminechloroplatinum(॥) $]^{+}\left[\mathrm{Pt}(॥) \mathrm{Cl}\left(\mathrm{NH}_{3}\right)_{3}\right]^{+}$(9), $\mathrm{Pt}\left[\mathrm{N}\left(p-\mathrm{HC}_{6} \mathrm{~F}_{4}\right) \mathrm{CH}_{2}\right]_{2} \mathrm{py}_{2}$ (12, Pt103), cisammine(3-bromopyridine)dichloroplatinum(II) $\left[\mathrm{PtCl}_{2}(3-\mathrm{Brpyr})\left(\mathrm{NH}_{3}\right)\right]$ (16, Brpyr = 3-bromopyridine), and a platinum complex with an anthrachinone ligand $\left[\mathrm{PtCl}_{2}(2 \mathrm{C} 3)\left(\mathrm{NH}_{3}\right)\right](18, \mathrm{Pt}-2 \mathrm{C} 3)$.

cause of cell death and treated cells showing no DNA damage have undergone apoptosis. ${ }^{44}$

Apart from the aforementioned Pt(II) complexes, there exists much interest in the use of $\mathrm{Pt}(\mathrm{IV})$ complexes as pro-drugs. ${ }^{45,46}$ Their mode of action is less understood and reduction of the $\mathrm{Pt}(\mathrm{Iv})$ precursor to a $\mathrm{Pt}(\mathrm{II})$ pro-drug followed by a hydrolysis step is argued (Fig. 3). ${ }^{47}$ The higher stability of octahedral Pt(Iv) complexes under physiological conditions reduces unwanted interactions with non-DNA biological nucleophiles and $\mathrm{Pt}$ related severe side effects. ${ }^{46,48}$ The main goals in the development of $\mathrm{Pt}(\mathrm{IV})$ complexes are: (i) oral application of $\mathrm{Pt}(\mathrm{IV})$ compounds, (ii) increase of its target selectivity (compared to $\mathrm{Pt}(\mathrm{II})$ complexes) via the modification of the axial ligands, and (iii) decrease in non-specific interactions (particularly with thiols) en route to the target sites, by increasing its kinetic inertness. ${ }^{47,48}$ One approach to overcome the early reduction through gastric juices is the use of nanobased delivering systems like carbon nanotubes, gold based nanoparticles and polymeric nanoparticles. ${ }^{5}$ Nonetheless, up to now, no Pt(Iv) compound has reached the status of an approved cancer drug (albeit entered clinical trials). ${ }^{5,37,39}$ 


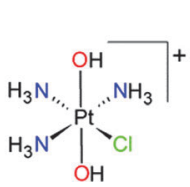

10



11

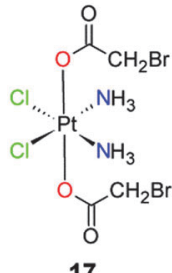

15

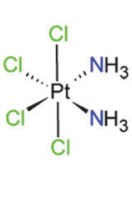

13

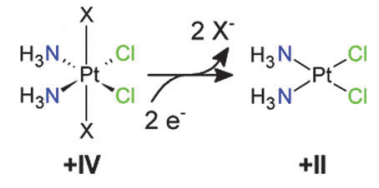

reduction scheme $\mathrm{Pt}(\mathrm{IV})$ to $\mathrm{Pt}(\mathrm{II})$
Fig. 3 The platinum(Iv) complexes. Top: trans, mer- $\left[\mathrm{Pt}(\mathrm{IV}) \mathrm{Cl}(\mathrm{OH})_{2}\left(\mathrm{NH}_{3}\right)_{3}\right]^{+}$(10), cis,trans,cis-[ $\left.\mathrm{PtCl}_{2}(\mathrm{OAC})_{2}\left(\mathrm{NH}_{3}\right)(\mathrm{NBA})\right]$ (NBA = n-butylamine) (11), cis-[Pt(IV)Cl $\left.\left(\mathrm{NH}_{3}\right)_{2}\right]$ (13), cis,trans, cis-[Pt(Iv) $\left.\mathrm{Cl}_{2}(\mathrm{OAc})_{2}\left(\mathrm{NH}_{3}\right)_{2}\right]$ (14). Bottom: cis, trans, cis-[Pt(Iv)Cl $\left.\mathrm{Cl}_{2}(\mathrm{OH})_{2}\left(\mathrm{NH}_{3}\right)_{2}\right]$ (15), and cis, trans, cis-[ $\left.\mathrm{PtCl} 2(\mathrm{OAcBr})_{2}\left(\mathrm{NH}_{3}\right)_{2}\right](\mathrm{OAcBr}=$ bromacetato) (17), and the Pt(Iv) to $\mathrm{Pt}($ ॥) reduction scheme.

Metallointercalators are a new class of platinum(II) DNAdamaging compounds active against $\mathbf{1}$ cisplatin and 3 oxaliplatin resistant cell lines. ${ }^{49-51}$ Dillon reported the synthesis and the mechanism of action of metallointercalator compounds, among them the platinum complexes [56MERR] (7, Fig. 2) and [56MESS] (8, Fig. 2). 72 [56MERR] and 8 [56MESS] are isomers possessing planar aromatic rings which can be inserted between the DNA base pairs. This non-covalent interaction unwinds the DNA double helix and is further stabilized through an overall positive charge of the complex. The resulting high selectivity for DNA make them promising highly toxic anti-cancer agents. ${ }^{52}$

\subsection{XAS and micro-SXRF investigations on platinum}

One of the first investigations on Pt anti-cancer compounds by means of XAS dates back to 1978 when Teo and Lippard et al. studied the binding of 1 cisplatin to calf thymus DNA. ${ }^{53}$ Since then, XAS has proven to be an invaluable technique in probing the reduction of $\mathrm{Pt}(\mathrm{IV})$ to $\mathrm{Pt}(\mathrm{II})$, as well as the changing coordination environment of the Pt(II) in cellulo and in different media environments.

2.1.1. The reduction of platinum(Iv) to platinum(II). XANES spectroscopy is a method of choice to quantify the proportion of platinum in its Pt(IV) and Pt(II) states in highly heterogeneous media (Fig. 4). Hambley et al. ${ }^{54}$ presented a method whereby the ratio $a / b$ of the absorbance maximum at the white line $a$ and the post edge minimum $b$ is linearly related to the content of $\mathrm{Pt}(\mathrm{IV})$, which was used to determine the percentage of Pt(Iv) present in an unknown sample. Daly et $a l^{55}$ applied this concept of the $\mathrm{Pt}(\mathrm{Iv}) / \mathrm{Pt}(\mathrm{II})$ ratio determination to determine the extent of reduction of the triamine platinum complexes $\mathbf{9}$ (Fig. 2) and $\mathbf{1 0}$ (Fig. 3) in cells. ${ }^{55}$ A2780 ovarian cancer cells were treated with 10 and XANES spectra were recorded from the pelleted cells. The proportion of $\mathrm{Pt}(\mathrm{IV})$ was determined to be $63 \%$ after $2 \mathrm{~h}$ and $13 \%$ after $24 \mathrm{~h}$ of incubation. The results showed the possibility of stabilizing triamine $\mathrm{Pt}(\mathrm{II})$ complexes as $\mathrm{Pt}(\mathrm{IV})$ complexes with longer lifespans under reducing conditions.

In a recent paper $^{56}$ the validity of the $\mathrm{Pt}(\mathrm{IV}) / \mathrm{Pt}(\mathrm{II})$ ratio method was further expanded to a number of platinum(IV) and platinum(II) complexes with different coordination spheres, and in different isomeric arrangements. ${ }^{56}$ The XANES spectra of six Pt(II) and twelve $\mathrm{Pt}(\mathrm{Iv})$ complexes were collected in phosphate buffered saline (PBS buffer). The standard curves were constructed with solutions of the $\mathrm{Pt}$ (IV) complexes and their corresponding Pt(II) analogues in fixed molar ratios from $0 \%$ to $100 \% \mathrm{Pt}(\mathrm{IV})$. The obtained ratios $a / b$ were the same for all $\mathrm{Pt}$ (II) complexes. In the case of the $\mathrm{Pt}$ (Iv) compounds the ratios $a / b$ increased with the number of oxygen ligands in the first coordination sphere. Nevertheless in all cases the linear relationship between the ratio $a / b$ and the $\operatorname{Pt}(\mathrm{Iv})$ content was preserved. The reduction of Pt(Iv) was monitored in cell growth medium (after 2, 14 and 24 h) and in A2780 ovarian cancer cells treated with the cis- and trans-Pt(Iv) anti-tumoural compounds (after 2 and $24 \mathrm{~h}$ ). The overall stability of the Pt(Iv) complexes in cell growth medium was higher, presumably as a result of the decreasing reducing power of the medium over time due to the oxidative effects of air. The stability of the compounds
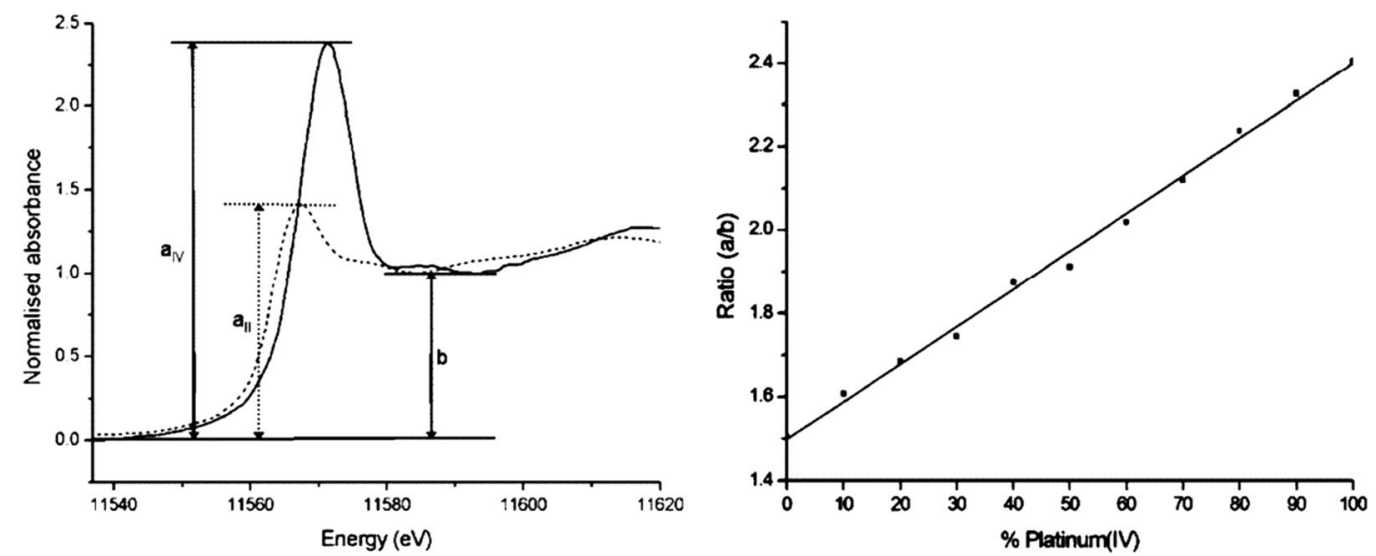

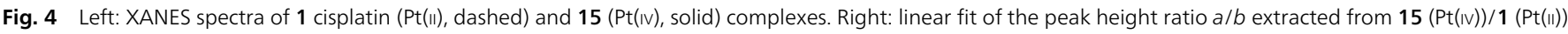

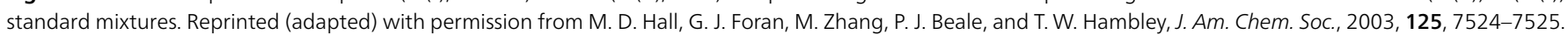
Copyright 2003 American Chemical Society. 
in A2780 cells was lower, with most of the trans-Pt(Iv) complexes reduced after $2 \mathrm{~h}$, whereas the cis-Pt(Iv) complexes were revealed to be more stable. ${ }^{56}$

2.1.2. Platinum compounds in the presence of reducing agents. Nemirovski et al. ${ }^{57}$ studied the reduction of the platinum(Iv) compound $\mathbf{1 1}$ (Fig. 3) by sodium ascorbate. ${ }^{57}$ The reduction process was monitored using $\left[{ }^{1} \mathrm{H},{ }^{13} \mathrm{C}\right]$ and $\left[{ }^{1} \mathrm{H}\right.$, ${ }^{15} \mathrm{~N}$ ] heteronuclear single quantum coherence nuclear magnetic resonance (HSQC-NMR). The intermediate peak present in the NMR spectra was identified with respect to its oxidation state using XANES. The $\mathrm{Pt}(\mathrm{Iv}) / \mathrm{Pt}(\mathrm{II})$ ratio was determined with the peak height ratio method developed by Hall et al. ${ }^{54}$ which made it possible to quantify a ratio of $20 \% \mathrm{Pt}(\mathrm{IV})$ to $80 \% \mathrm{Pt}(\mathrm{II})$ in the intermediate reaction mixture.

Studies on the interaction of $\mathbf{1}$ cisplatin and $\mathbf{2}$ carboplatin with reduced glutathione (GSH) were conducted by Obata et $a l .{ }^{58}$ As explained in Section 7, elements next to each other in the periodic table are hard to distinguish in XAS analysis. However, the replacement of light scatterers (e.g. N/O) through heavy scatterers $($ e.g. $\mathrm{S} / \mathrm{Cl})$ is possible and was studied with $\mathrm{Pt}$ $\mathrm{L}_{\mathrm{III}}$-edge EXAFS in this article. The experiments were carried out in PBS buffer at room temperature in the presence of 10-fold excess GSH. The N/O peaks in the Fourier transform (FT) of the EXAFS at around 1.6 ̊ decreased monotonically whereas the $\mathrm{Cl} / \mathrm{S}$ peak at around $2.0 \AA$ increased in the same manner. Following 180 and $930 \mathrm{~min}$, a vast majority of the N/O ligands were observed to be exchanged for 1 cisplatin and $\mathbf{2}$ carboplatin. The advantage of EXAFS in monitoring these highly heterogenic systems without the need of labelling with expensive isotopes like ${ }^{15} \mathrm{~N}$ or ${ }^{195} \mathrm{Pt}$ was clearly shown.

2.1.3. Stability of platinum complexes in solution. Provost et al. made several studies on the Pt(II) compounds 1 cisplatin, 2 carboplatin and 3 oxaliplatin. ${ }^{59-64}$ The reactions of these three compounds in chloride containing solutions of different $\mathrm{pH}$ values were studied. ${ }^{60,61}$ XANES and EXAFS analyses showed that 2 carboplatin decomposed to 1 cisplatin under acidic conditions and at chloride concentrations $>0.9 \% \mathrm{w} / \mathrm{w}$. The compound 3 oxaliplatin was shown to be less stable, with slowest degradation rates in neutral $\mathrm{NaCl}$ solutions sped up with decreasing $\mathrm{pH}$ values. In a subsequent study ${ }^{64}$ the degradation of 3 oxaliplatin from its original configuration diammino-cyclohexane-Pt(II)-oxalate (DACH-Pt(II)-Ox) (Fig. 2) to DACH-Pt(II)-Cl $\mathrm{Cl}_{2}$ could be shown, applying multiple scattering EXAFS analysis. The decomposition product was the same in neutral $\mathrm{NaCl}$ and acidic hydrochloric acid solutions. The fact that 2 carboplatin and 3 oxaliplatin decompose to $\mathbf{1}$ cisplatin or cisplatin-like drugs in chloride containing solutions is of high importance for the formulation and storage of infusion solutions. With a view to minimize the severe side effects - for example nephro- or ototoxicity - of $\mathbf{1}$ cisplatin, $\mathbf{2}$ carboplatin and $\mathbf{3}$ oxaliplatin, the degradation products of these compounds with diethyl-dithiocarbamate (DDTC) have been studied. DDTC is recommended by the World Health Organization for the destruction of 1 cisplatin. ${ }^{63}$ The compounds 1 cisplatin and 2 carboplatin exhibited the same FT after interaction with DDTC while the FT spectra for 3 oxaliplatin exhibited lower amplitudes (see Fig. 5). The final first shell coordination was identified as centro-symmetric square planar with four $\mathrm{S}$ atoms in the first shell of $\mathbf{1}$ cisplatin and 2 carboplatin, and two $\mathrm{N}$ and two $\mathrm{S}$ atoms in the first shell of 3 oxaliplatin. In the case of 3 oxaliplatin the exchange of the bidentate oxalate ligand by a bidentate DDTC ligand was shown. The investigations where expanded to other sulfur nucleophiles, namely cysteine (Cys), GSH, D-methionine, sodium thiosulfate and potassium thiocyanate. ${ }^{59}$ The prepared solutions of 2 carboplatin and 3 oxaliplatin with the previous mentioned compounds were measured right after preparation, after three days, two weeks and one month. The outcome of these studies demonstrated the possible inactivation of $\mathrm{Pt}$ (II) anti-cancer drugs by DDTC and other sulfur nucleophiles.

2.1.4. Platinum micro-X-ray fluorescence. Micro-SXRF mapping has been proven to be an invaluable tool for determining the distribution and concentration of platinum species within biological samples. Ilinski et $a{ }^{30}{ }^{30}$ demonstrated the feasibility of using micro-SXRF to detect clinical doses of an anti-cancer drug in single cells. The concentrations and uptake rates of 1 cisplatin and $\mathbf{1 2}$ (Pt103, Fig. 2) in cisplatin sensitive and resistant ovarian cancer cells were investigated. The concentration of $\mathrm{Pt}$ could be detected up to 5-10 ppm or 20 attograms $\left(2 \times 10^{-17} \mathrm{~g}\right)$ in a beam spot size of $1 \times 0.2 \mu \mathrm{m}^{2}$. For future studies a resolution of up to $150 \mathrm{~nm}$ for the investigation of cell sections has been postulated.

The cellular distributions of $\mathbf{1}$ cisplatin and its Pt(Iv) analogues 13, 14, and 15 (Fig. 3) were analyzed using micro-SXRF by Hambley et al. ${ }^{65}$ These four compounds display a similar cellular distribution with Pt localized in the nucleus. Micro-XANES spectra collected on areas of high Pt concentration in the cells revealed that the complex 15 with dihydroxo axial ligands is the most resistant against reduction to $\mathrm{Pt}(\mathrm{II})$.

In a subsequent step A2780 cancer cells treated with the bromine labelled Pt(II) compound 16 (Fig. 2) and the Pt(Iv) compound 17 (Fig. 3) were investigated with micro-SXRF. ${ }^{66}$ The bromine labelled ligands have replaced an amine ligand in the Pt(II) complex 16 and an axial ligand in the Pt(IV) complex 17. The dissociation of the bromine labelled axial ligands from 17 was used to monitor reduction to Pt(II). In the case of compound $\mathbf{1 6}$ the $\mathrm{Pt}$ and $\mathrm{Br}$ distributions were the same confirming the amine ligands as non-leaving groups. In the case of $\mathbf{1 7}$ the bromine distribution was more diffuse pointing toward the reduction of a substantial amount of the Pt(Iv) complexes to Pt(II). However, it could not be determined if the reduction took place extra- or intracellularly. Furthermore, control A2780 cells treated with the unlabelled 1 cisplatin showed unexpected endogenous levels of bromine, but at substantially lower concentrations. ${ }^{66}$ Micro-SXRF investigations were undertaken on mouse tumour thin sections (4T1.2 neo 1 mammary tumour) derived from 15 (Fig. 3) treated $\mathrm{Balb} / \mathrm{c}$ mice and on A2780 ovarian cancer cells treated with the intercalating complex 18 (Pt-2C3, Fig. 2). ${ }^{66}$ Due to the phosphate backbones of DNA, the phosphorous distribution within the A2780 cells is likely to correspond to the distribution of cellular DNA. The Pt distribution exhibited high co-localization with the phosphorous distribution, consistent with the selective DNA targeting abilities of the intercalating ligand. ${ }^{66}$ 

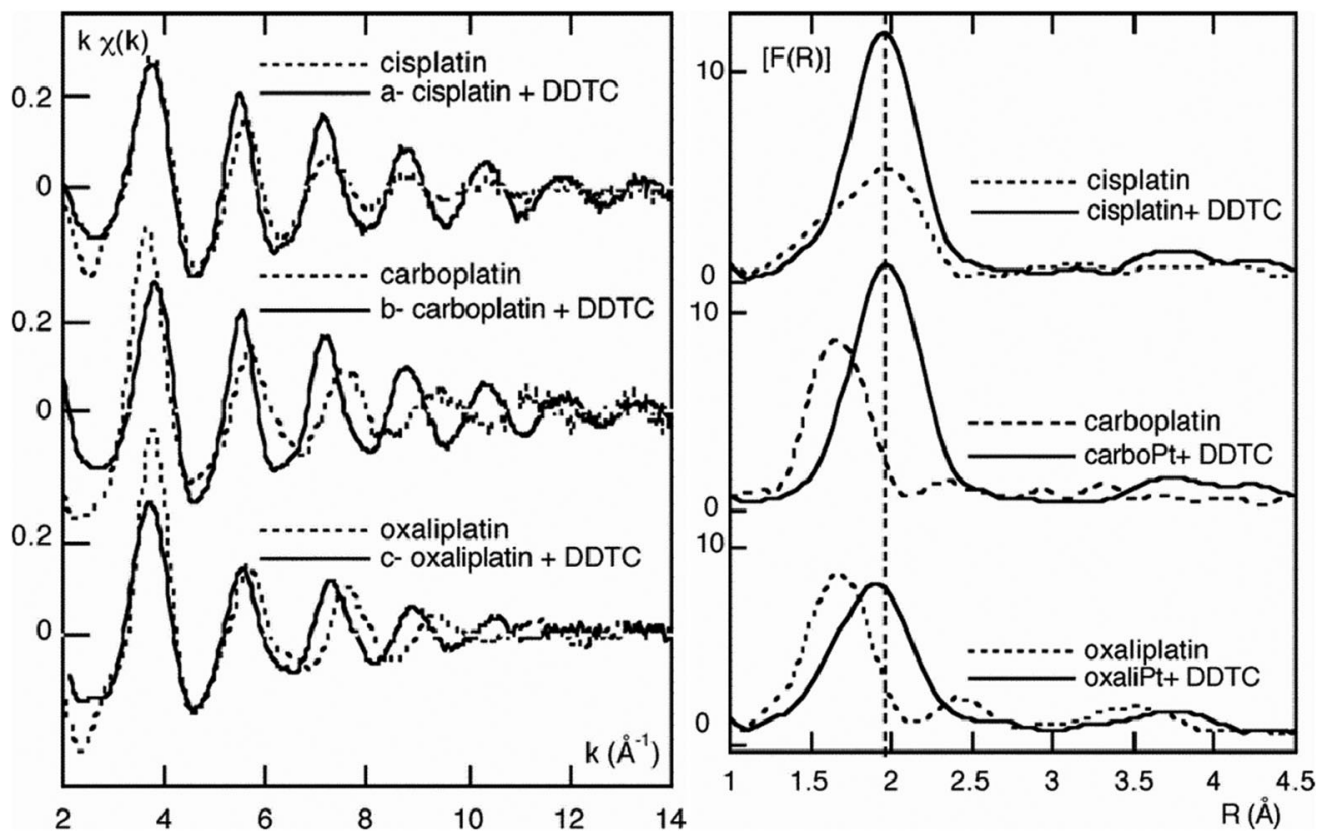

Fig. 5 Left: comparison of EXAFS spectra before and after reaction between diethyl-dithiocarbamate (DDTC) and 1 cisplatin, 2 carboplatin, or 3 oxaliplatin. Right: comparison of Fourier transform amplitudes before and after reaction between DDTC and 1 cisplatin, 2 carboplatin, or 3 oxaliplatin. The replacement of N/O through $\mathrm{Cl} / \mathrm{S}$ introduces a change in the FT peaks. Reprinted (adapted) with permission from: D. Bouvet, A. Michalowicz, S. Crauste-Manciet, D. Brossard, and K. Provost, Inorg. Chem., 2006, 45, 3393-3398. Copyright 2006 American Chemical Society.

Davis et al. ${ }^{67}$ applied micro-SXRF to thin sections of A549 lung cancer cells treated with 1 cisplatin and the metallointercalators 7 [56MERR] and 8 [56MESS] (Fig. 2). The Pt in 7 [56MERR] and 8 [56MESS] treated cells was clearly co-localized with phosphorus, which points toward a main interaction with the densely packed DNA in the heterochromatin regions of the nucleus (see Fig. 6c and d).

Zhang et al. ${ }^{68}$ used SXRF tomography and 2D X-ray fluorescence microscopy (2D-XFM) to study the bio-distribution of several anticancer platinum(II) complexes, among them 1 cisplatin, in a solid tumour model. Cryo-sectioning and cryo-fixing techniques were revealed to be less invasive than formalin fixing and more suitable for distribution studies of metal compounds in biological tissues. SXRF tomography allowed the drug distribution to be studied without the use of chemical fixatives, physical sectioning and lyophilisation. For the first time the good penetration of 1 cisplatin through DLD-1 colorectal cancer cell spheroids could be shown. SXRF tomography has a complicated experimental setup, and 2D-XFM was pointed out as a suitable, less complex alternative showing only minor changes in the observed metal distribution patterns in comparison to SXRF tomography. ${ }^{68}$

\section{Ruthenium compounds}

The most promising $\mathrm{Ru}$ compounds investigated so far show anti-tumour activity exceeding that of Pt-compounds or other cytostatic agents (e.g. in colorectal carcinomas in vivo and a variety of primary explanted human tumours in vitro). ${ }^{2,69,70}$ Compared to $\mathrm{Pt}$ compounds the $\mathrm{Ru}$ complexes cause less side effects and cellular resistance occurs to a lesser extent., ${ }^{2,71}$ (a)
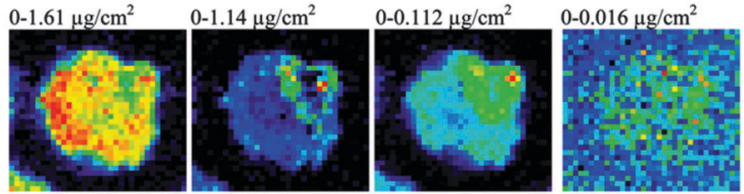

(b)
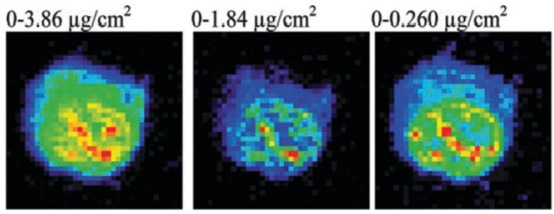

$0-0.0665 \mu \mathrm{g} / \mathrm{cm}^{2}$

(c)
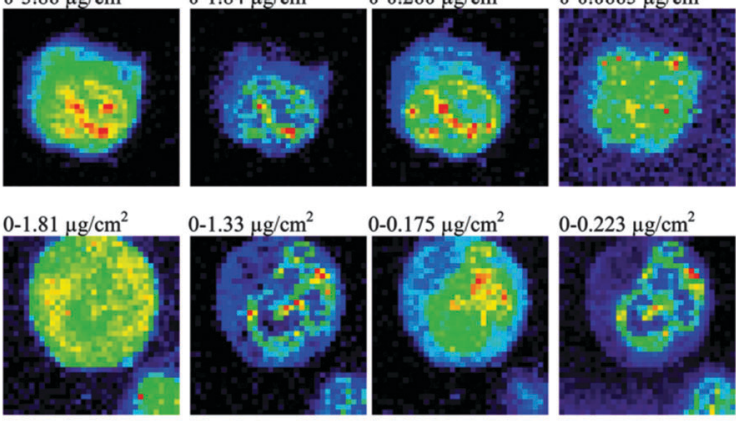

(d)

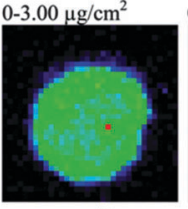

$\mathbf{S}$

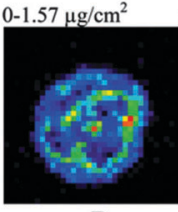

$\mathbf{P}$

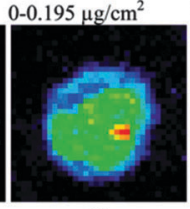

$\mathrm{Zn}$
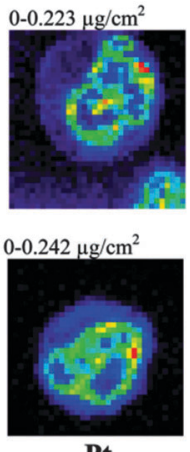

Pt

\section{Min}

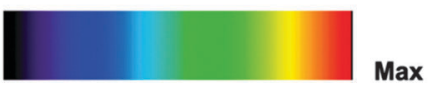

Fig. 6 Micro-SXRF elemental maps for A549 cells following treatment $(4 \mathrm{~h})$ with: (a) cell medium, (b) 1 cisplatin, (c) 7 [56MERR] and (d) 8 [56MESS]. Reprinted (adapted) with permission from K. J. Davis, J. A. Carrall, B. Lai, J. R. Aldrich-Wright, S. F. Ralph, and C. T. Dillon, Dalton Trans., 2012, 41, 9417. Copyright 2012 Royal Society of Chemistry. 
The overall chemical and pharmacokinetic behaviour of $\mathrm{Ru}$ is quite different from Pt compounds, ${ }^{72}$ as reflected in extensive protein binding which questions the relevance of DNA interactions in vivo.

\subsection{Octahedral ruthenium complexes (KP1019/KP1339 and NAMI-A)}

The Ru-complex KP1019 (19, Fig. 7) ${ }^{73}$ has shown promising anti-cancer activity $^{70}$ and its sodium analogue KP1339 (20, Fig. 7$)^{74}$ is in a clinical phase I-IIa study, ${ }^{75}$ whereas NAMI-A (21, Fig. 7 $)^{76,77}$ has shown activity mainly against metastases. ${ }^{72,78}$ Fast uptake of 19 KP1019 and 20 KP1339 by the cell was shown and initiation of apoptosis was indicated by caspase activation. ${ }^{75}$ The uptake mechanism of 19 KP1019 and 20 KP1339 may

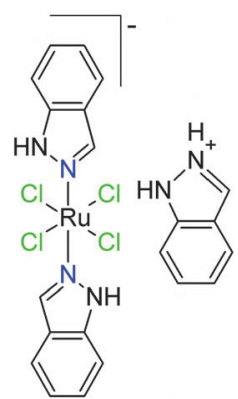

19 (KP1019)

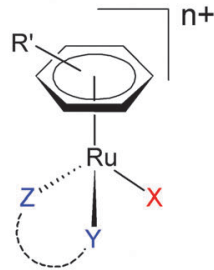

$\eta^{6}$-arene complexes

$\mathrm{X}: \mathrm{Cl}^{-}, \mathrm{SR}^{-}, \mathrm{pta}, \mathrm{pyr},$.

Y-Z: en, acac, $\mathrm{Cl}^{-}$...

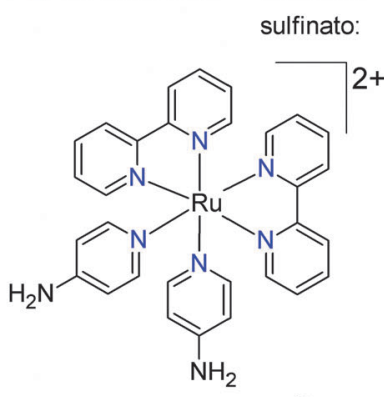

$23\left[\mathrm{Ru}(\mathrm{bpy})_{2}(4 \mathrm{AP})_{2}\right]^{2+}$

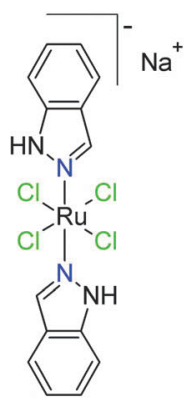

20 (KP1339)

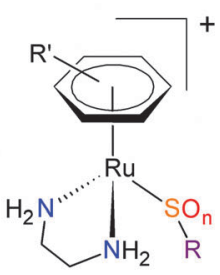

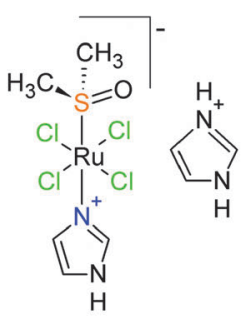

21 (NAMI-A)

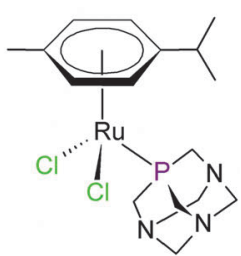

$\left(\eta^{6}\right.$-arene) Ru(en)(SO $\left.\mathrm{R}\right)$

thiolato: $\quad n=0 \mathrm{SR}^{-}$

$\mathrm{n}=1 \mathrm{SOR}^{-}$

$\mathrm{n}=2 \mathrm{SO}_{2} \mathrm{R}^{-}$

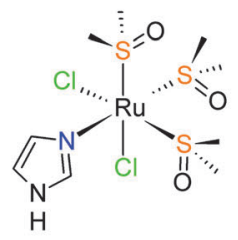

24 cis, $\mathrm{fac}_{-}\left[\mathrm{RuCl}_{2}(\mathrm{DMSO})_{3}(\mathrm{Im})\right]$
Fig. 7 Top: the Ru anti-cancer drugs indazolium-trans-[tetrachlorobis(indazole)ruthenate(II)] (19, KP1019), sodium-trans-[tetrachlorobis(indazole)ruthenate(II)] (20, KP1339), and imidazolium trans-[imidazoledimethyl-sulfoxide-tetrachlororuthenate] (21, NAMI-A). Center: the general formula of $\eta^{6}$-arene complexes, the $\eta^{6}$-arene thiophenolate complex $\left[\left(\eta^{6} \text {-arene) Ru(en) }\left(\mathrm{SO}_{n} \mathrm{R}\right)\right]^{+}\right.$, and $\left[\mathrm{Ru}\left(\eta^{6}-p\right.\right.$-cymene)$\mathrm{Cl}_{2}$ (pta)] (22, RAPTA-C, pta = 1,3,5-triaza-7-phosphatricyclo-[3.3.1.1]decanephosphine). Bottom: the photoactive bipyridine complex $\left[R u(b p y)_{2}(4 A P)_{2}\right]^{2+}(23$, bpy $=$ 2,2'-bipyridine, 4AP = 4-aminopyridine), and the Ru(॥) complex cis,fac-[dichlorobis(trisdimethylsulfoxide)imidazole-ruthenate(॥)] (24). en ethylenediamine, pyr pyridine, acac acetylacetonato. involve the iron transport protein transferrin (Tf) and the $\mathrm{Tf}$ receptor, which is over-expressed in tumour cells to meet their increased demand for iron. ${ }^{79}$ Another possible transport protein is human serum albumin (HSA). ${ }^{80}$ Once the ruthenium compound is inside the cell a pro-drug function is hypothesised and the reduction of $\mathrm{Ru}(\mathrm{III})$ to $\mathrm{Ru}(\mathrm{II})$ within this process is under debate. The electrochemical potential of $\mathrm{Ru}(\mathrm{III}) / \mathrm{Ru}(\mathrm{II})$ is accessible under physiological conditions and GSH and singleelectron transfer proteins are able to reduce $\mathrm{Ru}(\mathrm{III})$ in the presence of NADH. ${ }^{79}$

The main targets of 21 NAMI-A are located in the extracellular matrix ${ }^{81-83}$ and several studies on different tumour types and cell lines confirmed this main site of action. ${ }^{84,85}$ The compound alters the extracellular matrix of the solid tumours, accompanied by accumulation of the tumour cells in the $\mathrm{G}_{1} / \mathrm{G}_{0}{ }^{85}$ or $\mathrm{G}_{2}{ }^{86}$ phase and a decrease of cells present in the $\mathrm{S}$ phase of the cell cycle.

\subsection{Organometallic ruthenium arene compounds}

Organo-metallic photoactive $\mathrm{Ru}$-bipyridine and $\mathrm{Ru}-\eta^{6}$-arene complexes draw increasing interest due to their selective antiproliferative properties. ${ }^{87,88}$ The $\eta^{6}$-arene $\mathrm{Ru}$ compounds of the form $\left[\left(\eta^{6} \text {-arene) } \mathrm{Ru}(\mathrm{en}) \mathrm{Cl}\right]^{+}\right.$(see Fig. 7 ) for example are activated through hydrolysis in vivo in environments low in $\mathrm{Cl}^{-}$, like the cell nucleus. ${ }^{87}$ The hydrolyzed species $\left[\left(\eta^{6} \text {-arene }\right) \mathrm{Ru}(\mathrm{en})\left(\mathrm{H}_{2} \mathrm{O}\right)\right]^{2+}$ is capable of binding to DNA, with high affinity to the N7 position of guanine bases, ${ }^{87}$ forming only monofunctional DNA adducts. ${ }^{89}$ In general, the cytotoxicity of $\mathrm{Ru}$-arene complexes can be influenced by the nature of the $\eta^{6}$-arene ligand, the bidentate chelating ligand (Y-Z) and the leaving group X (see Fig. 7). ${ }^{87}$ Complexes with extended $\eta^{6}$-arene ligands (e.g. biphenyl) show higher ability to bind to DNA due to an increased intercalating effect. ${ }^{88}$ Complexes with a readily aquated leaving group $\mathrm{X}(\mathrm{X}=$ halide $)$ are more active than those with a non-aquating ligand $(\mathrm{X}=$ pyridine, pyr)..$^{90}$ An exception is $\left[\left(\eta^{6} \text {-arene }\right) \mathrm{Ru}(\mathrm{en})\left(\mathrm{SO}_{n} \mathrm{R}\right)\right]^{+}$ (Fig. 7) with a thiophenolate leaving ligand X. Thiophenolate is relatively inert to hydrolysis, but the complex shows antiproliferative effects of the order of 1 cisplatin and 2 carboplatin. ${ }^{91}$ The activation may involve the oxidation of the thiolate $\left(\mathrm{SR}^{-}\right)$, which was studied by XAS. ${ }^{92}$ Another promising $\mathrm{Ru} \eta^{6}$-arene compound is RAPTA-C (22, Fig. 7), ${ }^{93}$ which has two hydrolysable $\mathrm{Cl}^{-}$binding sites and pta (pta = 1,3,5-triaza-7phosphatricyclo-[3.3.1.1]decanephosphine), an interesting alkylation site which can be used to modify the lypophilicity of the compound. ${ }^{94}$

\subsection{Photoactivatable polypyridyl ruthenium complexes}

The bipyridine $\mathrm{Ru}$ complexes are a class of photoactivatable metal complexes offering new possibilities of selective prodrug activation. ${ }^{95-98}$ The crucial step is the light induced dissociation of one or more ligands and the subsequent binding to biological target molecules. 23 (Fig. 7) is such a compound which transforms into a disubstituted product after photodissociation of two 4APs (4AP $=4$-aminopyridine). ${ }^{97,99}$ The two new binding sites are possible targets for an adduct formation with DNA and the introduction of lethal DNA crosslinks. ${ }^{99}$ 


\subsection{XAS and micro-SXRF investigations on Ru}

3.4.1. Octahedral ruthenium complexes (KP1019/KP1339 and NAMI-A) and their adducts. In a recent paper, 19 KP1019 and its analogue 20 KP1339 (Fig. 7) were investigated by means of XANES in solution and in tumour tissue. ${ }^{100}$ The concept of the coordination charge was used to assign possible coordinationoxidation pairs to the unknown sample spectra. The edge shifts of ruthenium model compounds, representing possible coordination motifs and oxidation states in vivo, and the calculated coordination charge revealed a linear relationship. 19 KP1019 was dissolved in citrate saline buffer (CS buffer, $\mathrm{pH} 3.5,37^{\circ} \mathrm{C}$ ) and incubated for $30 \mathrm{~min}$ and $4 \mathrm{~h}$, respectively. After $30 \mathrm{~min}$ and $4 \mathrm{~h}$ a shift of $+1.1 \mathrm{eV}$ with respect to the spectrum of solid $19 \mathrm{KP} 1019$ implied an average replacement of one chlorine ligand and a first coordination environment of $\mathrm{Ru}(\mathrm{III}) \mathrm{Cl}_{3} \mathrm{~N}_{2}(\mathrm{O} / \mathrm{N})$.

After $8 \mathrm{~h}$ of incubation in CS buffer the first shell environment and/or the oxidation state of the Ru center changed dramatically, which is displayed by a significant decrease in the edge energy position. In the presence of five-fold excess GSH ( 5 h in CS buffer), the best matching first shell coordinations were $\mathrm{Ru}(\mathrm{II}) \mathrm{Cl}_{3} \mathrm{~N}_{2} \mathrm{~S}$ and $\mathrm{Ru}(\mathrm{III}) \mathrm{ClN}_{2} \mathrm{~S}_{3}$. In comparison to CS buffer, the spectrum of 19

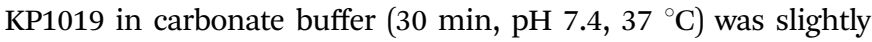
shifted to higher energies. A possible interaction with apotransferrin (apoTf) was indicated by a further shift to higher energies when apoTf was present under the same incubation conditions (30 min, $\mathrm{pH} \mathrm{7.4,} 37^{\circ} \mathrm{C}$ ). Independently of the used dosages and application schemes, 19 KP1019 and 20 KP1339 gave the same spectra in the mouse model, most consistent with a $\mathrm{Ru}(\mathrm{III}) \mathrm{Cl}_{3} \mathrm{~N}_{2}(\mathrm{O} / \mathrm{N})$ and $\mathrm{Ru}(\mathrm{II}) \mathrm{ClN}_{2}(\mathrm{O} / \mathrm{N})_{3}$ first shell. ${ }^{100}$

McFarlane et al. ${ }^{101}$ studied a spectrochemical series of Ru(III) and $\mathrm{Ru}(\mathrm{II})$ compounds, among them the anti-cancer complexes 19 KP1019 and 21 NAMI-A. Ruthenium $\mathrm{L}_{\mathrm{III} / \mathrm{II}}$-edge and chlorine K-edge XAS and density functional theory (DFT) calculations were used to investigate the electronic structure around the $\mathrm{Ru}$ metal center. The spectra of the $\mathrm{Cl}$ K-edge $(2822 \mathrm{eV})$ and $\mathrm{Ru}$ $\mathrm{L}_{\mathrm{III}}$ - and $\mathrm{L}_{\mathrm{II}}$-edge $\left(\mathrm{L}_{\mathrm{III}}=2838 \mathrm{eV}\right.$ and $\left.\mathrm{L}_{\mathrm{II}}=2967 \mathrm{eV}\right)$ were recorded at once. All Cl K-edge spectra for both $\mathrm{Ru}(\mathrm{III})$ and $\mathrm{Ru}$ (II) complexes exhibited pre-edge features, owing to the presence of vacant
$\mathrm{Ru} \mathrm{d}$ orbitals (see Fig. 8). Because of the strong ligand-field splitting of the Ru valence d-orbitals, the simple ground state configuration provides information about the spectral features. The chlorine pre-edges of the $\mathrm{Ru}(\mathrm{III})$ complexes are doublepeaked and separated by $1.5 \mathrm{eV}$ from each other (Fig. 8 left), representing the gap between the highest occupied molecular orbital (HOMO) and lowest unoccupied molecular orbital (LUMO) of the $\mathrm{Ru}$ metal center. These findings were also reproduced through the DFT calculations. The changes in the numbers of dimethyl sulfoxide (DMSO) molecules and imidazole ligands within the measured complexes had no significant effect on the overall electronic structure. This was partly ascribed to the large effective nuclear charge of $\mathrm{Ru}(\mathrm{III})$ and the counteracting effect of $\sigma$-donors and $\pi$-accepting roles of trans DMSO sulfur ligands. The variations in the $\mathrm{Ru} \mathrm{L}_{\mathrm{III}}$-edge peak positions and intensities of the $\mathrm{Ru}(\mathrm{III})$ compounds were greater than in the Cl K-edge spectra, with 19 KP1019 showing the highest peak energy and intensity. This was consistent with the highest effective nuclear charge for 19 KP1019 which lowers the $2 \mathrm{p}$ level and raises the $\mathrm{L}_{\mathrm{III}}$-edge energy transition, reflected in a $12 \%$ higher $\mathrm{L}_{\mathrm{III}}$ pre-edge feature than for its imidazole analogue trans-[tetrachlorobis-(1H-imidazole)ruthenate(III)] (KP418). ${ }^{102}$ The spectral differences of the $\mathrm{Ru}(\mathrm{II})$ complexes were less pronounced and the $\mathrm{L}_{\mathrm{III}}$ edge positions showed only slight variations within the experimental error. The high similarities are explained as a limitation of the ligand-to-metal donations when reaching a combination of ligands around two DMSO, two $\mathrm{Cl}^{-}$and two imidazoles coordinated to the $\mathrm{Ru}(\mathrm{II})$ center.

Lay and coworkers ${ }^{103}$ postulated that 21 NAMI-A binds to bovine serum albumin (BSA) via surface-donor groups, like histidine and methionine residues, rather than to a specific binding site. Freeze dried samples of 21 NAMI-A/BSA (1:1 mM), 21 NAMI-A/BSA (4:1 $\mathrm{mM}), 21$ NAMI-A/bovine serum (0.5:0.6 $\mathrm{mM})$ and 21 NAMI-A in cell culture medium supplemented with $2 \%$ fetal calf serum were investigated with Ru K-edge XAS. The resulting spectra were fitted with linear combinations of spectra from $\mathrm{Ru}(\mathrm{III})$ complexes with $\left[\mathrm{Ru}\left(\mathrm{NH}_{3}\right)_{6}\right] \mathrm{Cl}_{3}\left(\mathrm{Ru}(\mathrm{III}) \mathrm{N}_{6}\right),\left[\mathrm{Ru}_{3} \mathrm{O}(\mathrm{OAc})_{6}\left(\mathrm{OH}_{2}\right)_{3}\right](\mathrm{OAc})$
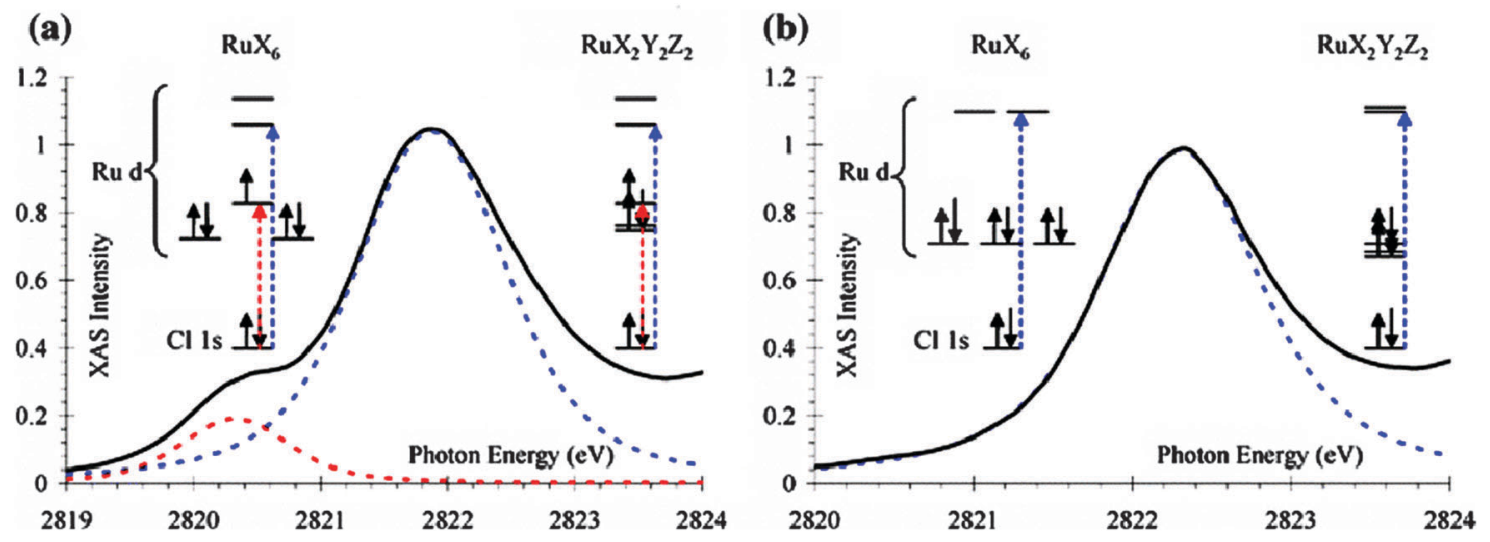

Fig. $8 \mathrm{Cl} \mathrm{K-edge} \mathrm{X-ray} \mathrm{absorption} \mathrm{near} \mathrm{edge} \mathrm{structure} \mathrm{spectra} \mathrm{with} \mathrm{corresponding} \mathrm{molecular} \mathrm{orbital} \mathrm{diagrams} \mathrm{of} \mathrm{the} \mathrm{d} \mathrm{manifold} \mathrm{for} \mathrm{(a)} \mathrm{Ru(III)} \mathrm{compound} 21 \mathrm{NAMI-A}$ and (b) Ru(II) compound 24 (see also Fig. 7). Reprinted (adapted) with permission from: T. V. Harris, R. K. Szilagyi, and K. L. McFarlane Holman, J. Biol. Inorg. Chem., 2009, 14, 891-898. With kind permission from Springer Science and Business Media. Copyright 2009. 
$\left(\mathrm{Ru}(\mathrm{III}) \mathrm{O}_{6}\right)$ and $\mathrm{K}_{2}\left[\mathrm{RuCl}_{5}\left(\mathrm{OH}_{2}\right)\right] \cdot \mathrm{H}_{2} \mathrm{O} \quad\left(\mathrm{Ru}(\mathrm{III}) \mathrm{Cl}_{5} \mathrm{O}\right)$ first shell environments. The resulting fits pointed toward a replacement of the S/Cl ligands of 21 NAMI-A in biological media mainly through N/O ligands. In the linear regression analysis of 21 NAMI-A in cell culture medium a significant proportion of $16 \%$ was constituted by $\mathrm{Ru}(\mathrm{III}) \mathrm{Cl}_{5} \mathrm{O}$, explained with incomplete $\mathrm{S} / \mathrm{Cl}$ replacement or binding to $\mathrm{Cl}^{-}$ions present in the cell culture medium. ${ }^{103}$

Ascone et al. ${ }^{104}$ used ruthenium $\mathrm{K}$ - and $\mathrm{L}_{\mathrm{III}}$-edge, chlorine K-edge and sulfur K-edge XAS to identify the oxidation state and the ligand exchange reactions during the 21 NAMI-A/BSA adduct formation. The $\mathrm{Ru} \mathrm{L}_{\mathrm{III}}$-edge spectra resembled two distinct peaks separated by $3 \pm 0.3 \mathrm{eV}$ (denoted A and B bands). The A-bands of the model ruthenium(III) acetylacetonate $\left(\mathrm{Ru}(\mathrm{acac})_{3}\right), 21$ NAMI-A and the 21 NAMI-A/BSA adduct are at the same position. The B-bands of the 21 NAMI-A/BSA adduct and $\mathrm{Ru}(\mathrm{acac})_{3}$ are shifted to higher energies by $+0.8 \mathrm{eV}$ compared to 21 NAMI-A. The Ru K-edge spectra of the 21 NAMI-A/BSA adduct and the $\mathrm{Ru}(\mathrm{acac})_{3}$ spectra are shifted by $+4 \mathrm{eV}$ to higher energies with respect to the spectrum of 21 NAMI-A. The shifts in the $\mathrm{Ru} \mathrm{K}$ - and $\mathrm{L}_{\mathrm{III}}$-edge spectra confirm the unchanged $\mathrm{Ru}(\mathrm{III})$ oxidation state. The Cl K-edge spectra of 21 NAMI-A and the 21 NAMI-A/BSA adduct are quite different with a missing pre-edge and a decrease of about $-0.5 \mathrm{eV}$ in energy for the latter. This indicates a release of chlorine ligands when BSA binding took place. The sulfur K-edge data were dominated by 40 sulfur atoms of the BSA forming 17 disulfide bonds. The single-atom signal from 21 NAMI-A contributes only to a minor extent to the overall sulfur XAS spectrum. ${ }^{104}$

Microprobe X-ray fluorescence of tumour (SW480) thin sections from mice treated with $20 \mathrm{KP} 1339$ revealed a strong penetration of the $\mathrm{Ru}$ into all regions of the tumour tissue, with the highest concentrations near blood vessels and in the edge regions of the tissue samples. ${ }^{100}$

Micro-SXRF investigations on 19 KP1019 and 21 NAMI-A in single SH-SY5Y human neuroblastoma cells ${ }^{105}$ showed the correlation of the Ru and Fe distribution in 19 KP1019 treated cells, whereas for 21 NAMI-A this was not the case. About $50 \%$ of $19 \mathrm{KP} 1019$ was concentrated in the nuclear region. After treatment of the cells with 19 KP1019 the Fe distribution was altered and resembled the $\mathrm{Ru}$ one, with unchanged total Fe concentrations inside the cells. In contrast, no significant uptake into the cell was seen for 21 NAMI-A, which supports the assumption of an extracellular main site of action. The $\mathrm{Cu}$ concentration was significantly increased within the total cell and in the cell nucleus of 21 NAMI-A and 19 KP1019 treated cells. ${ }^{105}$

3.4.2. Photoactivatable ruthenium polypyridyl complexes. $\mathrm{Ru}$ K-edge EXAFS measurements on solid $\left[\mathrm{Ru}(\mathrm{bpy})_{3}\right] \mathrm{Cl}_{2}$ in boron nitride $(\mathrm{BN})^{106}$ and in aqueous solution $(1 \mathrm{mM}),{ }^{99}$ on $\left[\mathrm{Ru}(\mathrm{bpy})(4 \mathrm{AP})_{4}\right] \mathrm{Cl}_{2}{ }^{99,106}$ and 23 (Fig. 7) in aqueous solution $(10 \mathrm{mM})^{106}$ and on cis-[Ru(bpy $\left.)_{2}(\mathrm{py})_{2}\right] \mathrm{Cl}_{2}$ in aqueous solution $(50 \mathrm{mM})^{107}$ were used to validate the DFT optimized structures of these complexes. The solution structure and the oxidation states of the complexe cis-[Ru(bpy $\left.)_{2}(\mathrm{CO}) \mathrm{Cl}\right]^{+}$and its aquated derivative $c i s$ - $\left[\mathrm{Ru}(\mathrm{bpy})_{2}(\mathrm{CO}) \mathrm{H}_{2} \mathrm{O}\right]^{2+}$ were resolved with XAS. ${ }^{108}$ The same edge position and the high similarity in the XANES spectra confirmed the unchanged oxidation state of the $\mathrm{Ru}$ center in aqueous solution. Again EXAFS results were in good agreement with the DFT optimized solution structures and with the X-ray diffraction data of $c i s$ - $\left[\mathrm{Ru}(\mathrm{bpy})_{2}(\mathrm{CO}) \mathrm{Cl}\right]^{+}{ }^{108}$

3.4.3. Ruthenium arene complexes. Kennepohl et al. ${ }^{92}$ applied a combination of sulfur K-edge and ruthenium K-edge XAS and DFT techniques to study the activation of $\mathrm{Ru}(\mathrm{II})$-arene complexes of the type $\left[\left(\eta^{6} \text {-arene }\right) \mathrm{Ru}(\mathrm{en})\left(\mathrm{SO}_{n} \mathrm{R}\right)\right]^{+}(n=0,1,2$, $\mathrm{R}=$ phenyl or iso-propyl group, $\eta^{6}$-arene $=p$-cymene or hexamethylbenzene, Fig. 7). The $\mathrm{SR}^{-}$ligand oxygenation to sulfinate $\left(\mathrm{SO}_{2} \mathrm{R}^{-}\right)$via sulfenate $\left(\mathrm{SOR}^{-}\right)$and activation through protonation under acidic conditions was stated. Ru K-edge spectra of several thiolato, sulfenato and sulfinato complexes exhibited no changes in the $\mathrm{Ru}$ (II) center upon ligand oxidation. The missing of clearly observable pre-edge features indicated a ligand environment well described as pseudo-octahedral in all cases. ${ }^{109,110}$ The sulfur K-edge XAS spectra differed substantially with energy shifts of about $+3 \mathrm{eV}$ each from $\mathrm{SR}^{-}$to $\mathrm{SOR}^{-}$ and from $\mathrm{SOR}^{-}$to $\mathrm{SO}_{2} \mathrm{R}^{-}$(see Fig. 9). Combined XAS and DFT results indicated little impact of the sulfur oxidation state on the $\mathrm{Ru}-\mathrm{S}$ bond and $\mathrm{SR}^{-}$oxygenation was stated as insufficient

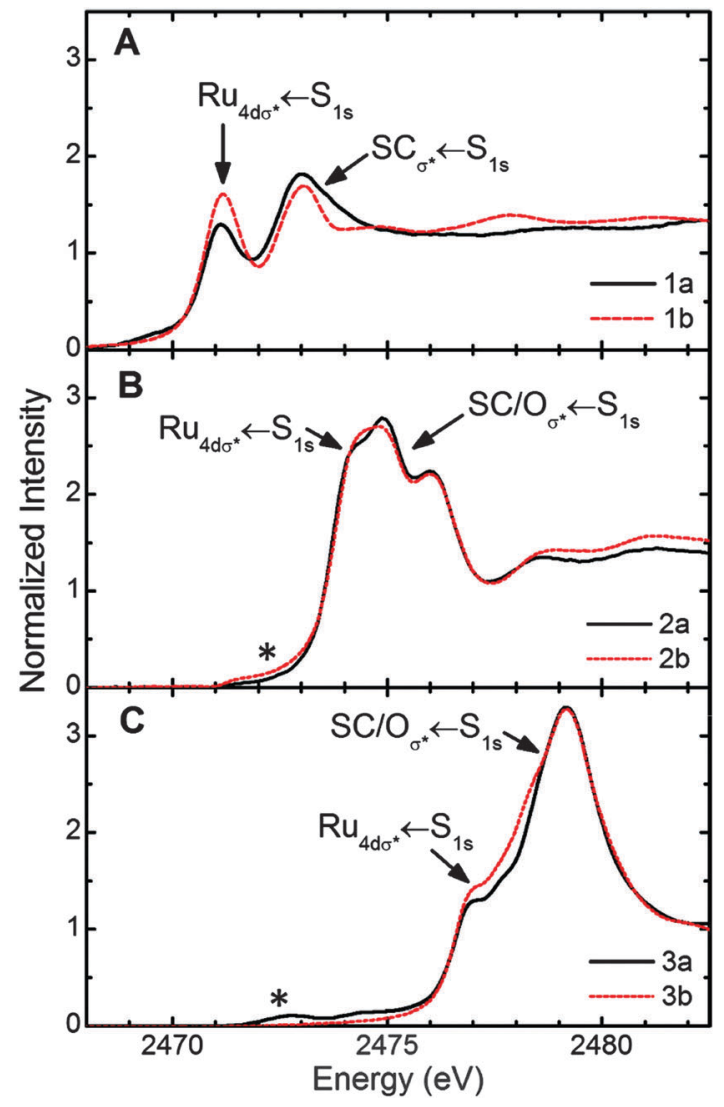

Fig. 9 Sulfur K-edge spectra of $\mathrm{Ru}(॥)\left[\left(\eta^{6} \text {-arene) } \mathrm{Ru}(\mathrm{en})\left(\mathrm{SO}_{n} \mathrm{R}\right)\right]^{+}(\mathrm{A})\right.$ thiolato $1 \mathrm{a}$ and $\mathbf{1 b}$, (B) sulfenato $\mathbf{2 a}$ and $\mathbf{2 b}$, and (C) sulfinato $\mathbf{3 a}$ and $\mathbf{3 b}$ complexes. An asterisk $\left(^{*}\right)$ represents features due to thiolate-based impurities in the sulfenato-sulfinato complexes. Reprinted (adapted) with permission from: T. Sriskandakumar, H. Petzold, P. C. A. Bruijnincx, A. Habtemariam, P. J. Sadler, and P. Kennepohl, J. Am. Chem. Soc., 2009, 131, 13355-13361. Copyright 2009 American Chemical Society. 
for the biological activation. Therefore, additional activation mechanisms are required to obtain a biological activity. ${ }^{92}$

\section{Gallium compounds}

Gallium(III) displays coordination characteristics similar to group 13 metal ions, but also to group 8 metal ions as iron(III). ${ }^{111}$ Gallium can bind to proteins which require the trivalent form of iron, but not to proteins requiring the divalent one. The uptake of $\mathrm{Ga}$ (III) into the cell is thought to be coupled to Tf and to compete with the iron transport process. ${ }^{112}$ The gallium bound to Tf is taken up by receptor mediated endocytosis. ${ }^{113}$ Although $\mathrm{Fe}(\mathrm{III})$ and $\mathrm{Ga}(\mathrm{III})$ have similar uptake mechanisms, they differ from each other in terms of intracellular transport processes. Iron is bound mainly to ferritin and undergoes a reduction and re-oxidation process. Gallium shows no change in the oxidation state under physiological conditions and is mostly present in the labile gallium pool. ${ }^{114}$ The above described uptake mechanism is generally based on experiments conducted with Ga-nitrate $\left(\mathrm{Ga}\left(\mathrm{NO}_{3}\right)_{3}\right)$ or other Ga-salts. Up to now it has not been fully clarified if the Tf coupled uptake process also applies to the Ga tumour inhibiting complexes such as 25 (KP46, Fig. 10) and 26 (gallium maltolate, Fig. 10). ${ }^{2}$

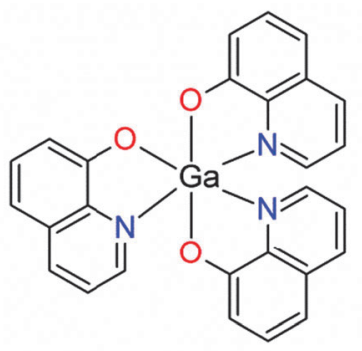

25 (KP46)<smiles></smiles>

26
Fig. 10 Anti-cancer gallium compounds tris(8-quinolinolato)gallium(III) (25, KP46), and tris(3-hydroxy-2-methyl-4H-pyran-4-one)gallium(III) (26, gallium maltolate).

\subsection{XAS and SXRF investigations on gallium}

The interaction of the anti-cancer complex 25 KP46 with possible transport molecules and the distribution of the compound in tumour and liver tissue were investigated with XAS and micro-XAS. ${ }^{115}$ The coordination environment of the metal center remains intact in the presence of apoTf and HSA (Fig. 11). The gallium distribution pattern in tumour and liver tissue revealed high similarities to the distribution patterns of $\mathrm{Zn}$ and $\mathrm{Fe}$, minor similarities to $\mathrm{Cu}$ and $\mathrm{Ni}$, and none to $\mathrm{Ca}$. The complex was observed to be very stable under physiological conditions, in cell culture media and in tissue samples.

The study of Bockman et al. ${ }^{116}$ is the first application of micro-X-ray fluorescence to $\mathrm{Ga}\left(\mathrm{NO}_{3}\right)_{3}$ and its interaction with the Ca pathway in cancer induced hypercalcemia. The incorporation of trace amounts of $\mathrm{Ga}$ into the bone material and the elemental distribution have been studied in vitro and in vivo. It was found that $\mathrm{Ga}$ is mainly reabsorbed in the metabolic active regions at the interface of the organic (collagen-associated) and the mineral components, where mineralization occurs. ${ }^{116}$ The coordination of Ga in newly formed bone material could be elucidated as Ga bound in a distorted octahedron with Ga-O distances of around $1.91 \AA^{117}$

\section{Gold compounds}

The sole clinical application of gold compounds presently is in the treatment of rheumatoid arthritis. ${ }^{118-120}$ Amongst these, the Au(I) complex, auranofin (27, Fig. 12), also exhibits anti-tumoural activity. ${ }^{120-122}$ Other gold(I) compounds used in chrysotherapy are gold(I) thioglucose (solganol), ${ }^{123}$ gold(I) sodium thiomalate (myochrysin), ${ }^{123}$ gold(I) thiopropanol sulphonate (allochrysine) ${ }^{124}$ and gold(I) bis(thiosulfate) (sanochrysine), ${ }^{124}$ which are all hydrophilic, except 27 auranofin which is hydrophobic. ${ }^{124}$

The most investigated gold compounds are $\mathrm{Au}(\mathrm{I})$ complexes with phosphine and carbene ligands, $\mathrm{Au}(\mathrm{III})$ dithiocarbamate compounds, $\mathrm{Au}(\mathrm{III})$ porphyrinates and organogold(III) compounds. The important oxidation states for gold in pharmacological
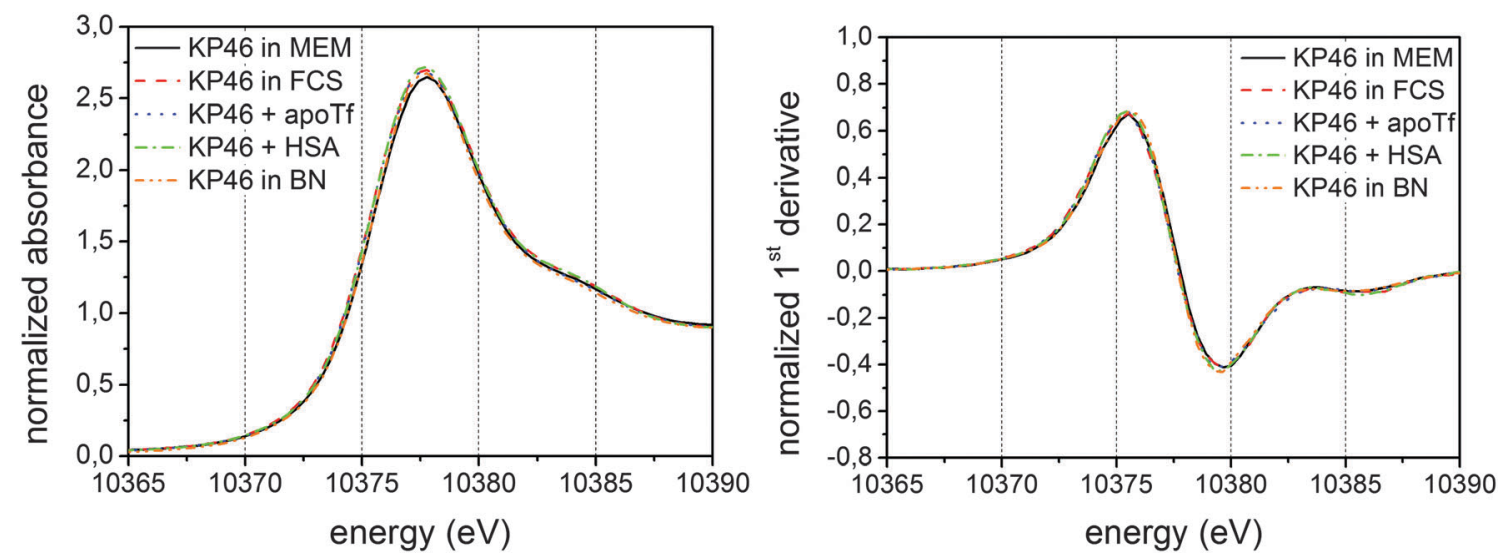

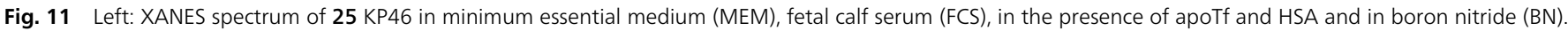

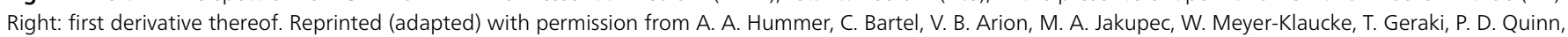
A. Mijovilovich, B. K. Keppler, and A. Rompel, J. Med. Chem., 2012, 55, 5601-5613. Copyright 2012 American Chemical Society. 


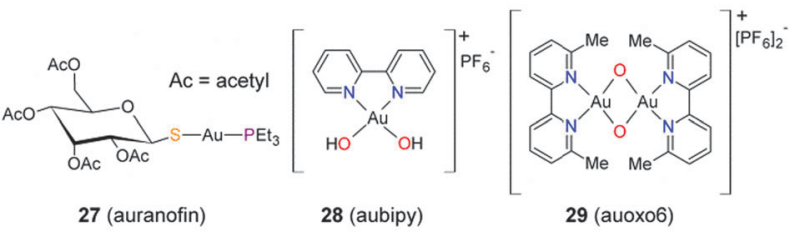

Fig. 12 Investigational anti-cancer $A u(I)$ and $A u(I I)$ compounds triethylphosphine(2,3,4,6-tetra-O-acetyl- $\beta$-1-D-thiopyranosato-S)gold(I) (27, auranofin), $\left[\mathrm{Au}(\mathrm{III})\left(2,2^{\prime}\right.\right.$-bipyridine $\left.)(\mathrm{OH})_{2}\right] \mathrm{PF}_{6}$ (28, aubipy), $\quad\left[\mathrm{Au}_{2}\left(6,6^{\prime}\right.\right.$-dimethyl-2,2'bipyridine $\left.)_{2}(\mu-\mathrm{O})_{2}\right]\left(\mathrm{PF}_{6}\right)_{2}(29$, auoxo6).

applications are gold(I) $\left(\mathrm{d}^{10}\right.$ linear dicoordinated) and gold(III) $\left(\mathrm{d}^{8}\right.$ square planar). ${ }^{124}$ The interchange between these two oxidation states is physiologically accessible and the high similarity to Pt(II) coordination and the electronic configuration $\left(\mathrm{d}^{8}\right)$ make $\mathrm{Au}(\mathrm{III})$ compounds very promising candidates for new anti-cancer drugs. ${ }^{125}$ In the last 20 years a variety of $\mathrm{Au}(\mathrm{III})$ compounds have been synthesized and tested against Pt resistant tumour cell lines. ${ }^{126,127}$ The main drawbacks of the $\mathrm{Au}(\mathrm{III})$ complexes are their instability under physiological conditions and their fast reduction to elemental gold. Au(III) is a strongly oxidizing "borderline" cation which shows preference for nitrogen donors, but also for "soft" donor ligands (like S, Se or cyanide), similar to the "soft" cation $\mathrm{Au}(\mathrm{I}) .{ }^{121,124,127,128}$

Two major biological targets could be elucidated for $\mathrm{Au}(\mathrm{I})$ compounds, the mitochondrial membrane and the selenoenzyme thioredoxin reductase (TrxR). ${ }^{124,129}$ The Cys and selenocysteine present in the active site of TrxR were revealed as an optimal target for the $\mathrm{Au}(\mathrm{I})$ complexes which show soft acid character. ${ }^{124}$ As TrxR protects the cell against oxidative stress, its inhibition causes the increase of reactive oxygen species and the damage of mitochondrial functions. ${ }^{130,131}$ Some of the $\mathrm{Au}(\mathrm{I})$ compounds like N-heterocyclic carbene complexes combine selective TrxR inhibition and mitochondrial membrane permeabilisation properties. ${ }^{132}$

The cytotoxic activity of $\mathrm{Au}$ (III) compounds is thought to be similar to the cytotoxicity proposed for $\mathrm{Au}(\mathrm{I})$, by preferentially targeting thiol, imidazole and selenol groups of proteins. ${ }^{127}$ The major cause of cytotoxicity is strongly dependent on the $\mathrm{Au}(\mathrm{III})$ ligands. For aurobipyridines (see Fig. 12) TrxR was observed as a major target. ${ }^{127}$ The Au(III) porphyrins instead showed a significantly higher affinity to DNA, causing fragmentation of genomic DNA. ${ }^{126}$ In the context of other possible targets in the cell the enzymes lipoamide dehydrogenase, glutathione reductase and mercuric ion reductase are mentioned, which are all members of the family of pyridine nucleotide oxidoreductases like TrxR. ${ }^{133}$ Messori et al. ${ }^{134}$ synthesized two promising anti-cancer agents bearing the bipyridyl motif: ${ }^{123,135}$ the $\mathrm{Au}(\mathrm{III})$ centered aubipy (28, Fig. 12) and the oxobridged dinuclear auoxo6 (29, Fig. 12). ${ }^{136-138}$ These gold bipyridine complexes showed considerable cytotoxic activity against 1 cisplatin resistant cell lines. ${ }^{127,131}$

\subsection{XAS investigations on gold}

A combination of $\mathrm{Au} \mathrm{L}_{\mathrm{III}}$-edge XANES and DFT was used to study the electronic configuration of 28 aubipy. ${ }^{139}$ A structure optimized with DFT calculations was used as an input for the

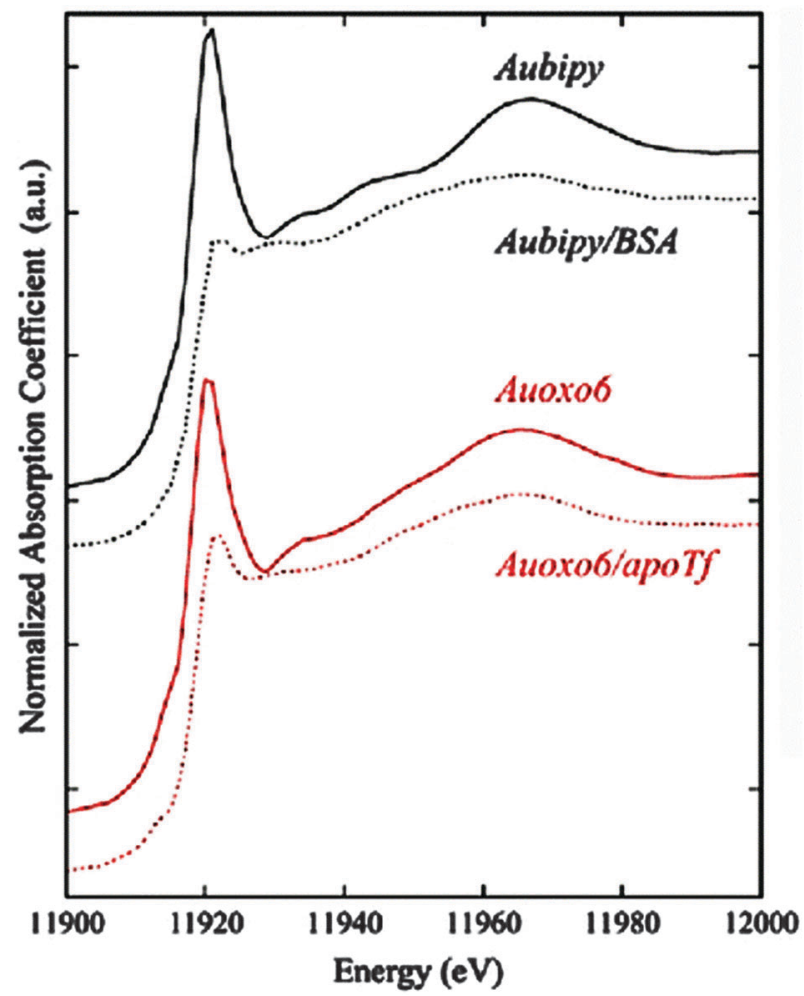

Fig. 13 Relevant changes in the oxidation states of 29 auoxo6 and $\mathbf{2 8}$ aubipy compared with their respective protein adducts are shown by XANES spectra. Reprinted (adapted) with permission from L. Messori, A. Balerna, I. Ascone, C. Castellano, C. Gabbiani, A. Casini, C. Marchioni, G. Jaouen, and A. C. Castellano, J. Biol. Inorg. Chem., 2010, 16, 491-499. With kind permission from Springer Science and Business Media. Copyright 2010.

calculation of theoretical XANES spectra. The HOMO-LUMO gap and the orbital shapes were determined as well. ${ }^{139}$

The three gold(I/III) compounds 27 auranofin, 28 aubipy and 29 auoxo6 were investigated by Messori $e t$ al. by means of $\mathrm{Au}$ $\mathrm{L}_{\text {III }}$-edge XAS. ${ }^{134}$ The binding of these three complexes to the potential transport proteins apoTf (of 27 auranofin and 29 auoxo6) and BSA (of 28 aubipy) and their potential changes in the oxidation state after $24 \mathrm{~h}$ in solution were studied $(50 \mathrm{mM}$ phosphate buffer, pH 7.4, 1:1 $10^{-4} \mathrm{M}$ ). The XANES spectra of the $\mathrm{Au}$ (III) 29 auoxo6/apoTf and 28 aubipy/BSA adducts clearly showed a reduction to $\mathrm{Au}(\mathrm{I})$ through a remarkable decrease in white line intensity (Fig. 13) and a shift of about $+1 \mathrm{eV}$ to higher energies, which is special for $\mathrm{Au}$ and reverse to an expected shift to lower energies in the case of a reduction. ${ }^{123,140}$ The EXAFS analysis of 29 auoxo6/apoTf and 28 aubipy/BSA revealed a decrease in coordination number from four to two, for each of the complexes. For 29 auoxo6/apoTf the loss of the $\mathrm{Au}-\mathrm{Au}$ peak in the FT was interpreted as a binding to apoTf of the now mononuclear 29 auoxo6 via $1.9 \pm 0.4 \mathrm{O}$ or $\mathrm{N}$ ligands. ${ }^{134}$ In the presence of apoTf the $\mathrm{Au}(\mathrm{I})$ compound 27 auranofin preserved its oxidation state +1 and the coordination number was still two, with slightly increased average S/P distances pointing toward an 27 auranofin/apoTf adduct formation via a protein thiol or thioether bond, most likely replacing the thiosugar ligand. 
Hill et al. ${ }^{141}$ used XAS to specify the binding partners of selenoauranofin $\left(\mathrm{Et}_{3} \mathrm{PAuSe}\right.$-tagl, tagl = tetraacetylglucose, $\mathrm{S}$ in 27 auranofin replaced through Se) by measuring the $\mathrm{Au} \mathrm{L}_{\mathrm{III}^{-}}$and Se K-edge of a solid powder sample. Gold was found to be in the oxidation state +1 and bound to one phosphor ligand, according to the peak intensity at $11928 \mathrm{eV}$, whose intensity is directly proportional to the number of $\mathrm{Au}-\mathrm{P}$ bonds. The lack of a strong $2 \mathrm{p} \rightarrow 5 \mathrm{~d}$ transition "white line" characteristic of $\mathrm{Au}(\mathrm{III})$ and the absence of the two peaks at $11945 \mathrm{eV}$ and $11967 \mathrm{eV}$ distinct for $\mathrm{Au}(0)$ clearly indicated the $\mathrm{Au}(\mathrm{I})$ state. The best fit of the FT could be achieved with $0.9 \mathrm{P}$ at $2.28 \AA$ and $1.6 \mathrm{Se}$ at $2.41 \AA$. At the Se K-edge three distinct peaks in the FT became visible. The peaks were best fitted with $1.2 \mathrm{C}$ at $1.91 \AA, 0.9 \mathrm{Au}$ at $2.39 \AA$ and a 1.4 second shell $\mathrm{P}$ at a non-bonded distance of $4.61 \AA$. The difference in the Au-Se distances determined over the $\mathrm{Au} \mathrm{L}_{\mathrm{III}}{ }^{-}$and Se K-edge EXAFS is only $0.02 \AA$. The sum of the $\mathrm{Au}-\mathrm{P}$ and $\mathrm{Au}-\mathrm{Se}$ distances from the $\mathrm{Au}$ $\mathrm{L}_{\text {III }}$ EXAFS data is $4.69 \AA$, which is in agreement with the direct fitted second shell $\mathrm{P}$ distance of $4.61 \AA$ from the Se K-edge XAS data. Furthermore, this high similarity in bond distances points toward a nearly linear $\mathrm{P}-\mathrm{Au}-\mathrm{Se}$ grouping. ${ }^{141}$

\section{Cobalt compounds}

Cobalt complexes serve as prodrugs and release cytotoxic ligands upon reduction. Research into this area has so far concentrated on four types of compounds: (i) hexacarbonyldicobalt complexes with alkyne ligands, (ii) $\left[\mathrm{Co}(\mathrm{III})\left(\mathrm{NH}_{3}\right)_{6}\right] \mathrm{Cl}_{3}$, (iii) Co(III) complexes with Schiff base ligands, (iv) Co(II) and/or $\mathrm{Co}$ (III) complexes with cytotoxic mustamine, mithramycin, and thiouracil ligands. ${ }^{6}$ In many solid tumours the rapid growth of the tumour tissue leads to insufficient vascularization and hypoxic conditions. Ware et al. studied the activation of $\mathrm{Co}$ (III) compounds containing $\mathrm{N}$-mustards under these conditions. ${ }^{142-145}$ The $\mathrm{Co}(\mathrm{III})$ center is reduced to $\mathrm{Co}(\mathrm{II})$ and the N-mustard ligand is released. ${ }^{146}$ The workgroup of Hambley developed the complex 30 (Fig. 14), which works as a carrier system for marimastat (mmst). ${ }^{147,148}$ Mmst itself is an inhibitor of matrix metalloproteinases, which are involved in tumour metastasis. ${ }^{149}$ It has been suggested that the selective activation depends on the rate of reoxidation. In normal oxygenated environments the complex is reduced and activated, but is then rapidly reoxidized and deactivated. Under hypoxic conditions the reoxidation rate is low and the activated anti-cancer agent is able to induce its action. ${ }^{6,70,150}$

\subsection{XAS investigations on cobalt}

6.1.1. Determination of the oxidation state of cobalt tumour inhibiting compounds. The XANES spectra of a set of $20 \mathrm{Co}$ (II) and $\mathrm{Co}$ (III) ${ }^{150,151}$ complexes were collected and their edge shapes were examined to assess the cobalt oxidation state. All measurements were conducted on aqueous solutions of the complexes and not on BN preparations. The Co(III) edge positions were on average $+1.5 \mathrm{eV}$ at higher energies than the Co(II) edges. ${ }^{150}$ The Co(III) complexes showed two absorption peaks at about $7727 \mathrm{eV}$ and $7736 \mathrm{eV}$ and a significantly decreased edge height. ${ }^{150}$ A small pre-edge feature at about $7709 \mathrm{eV}$,

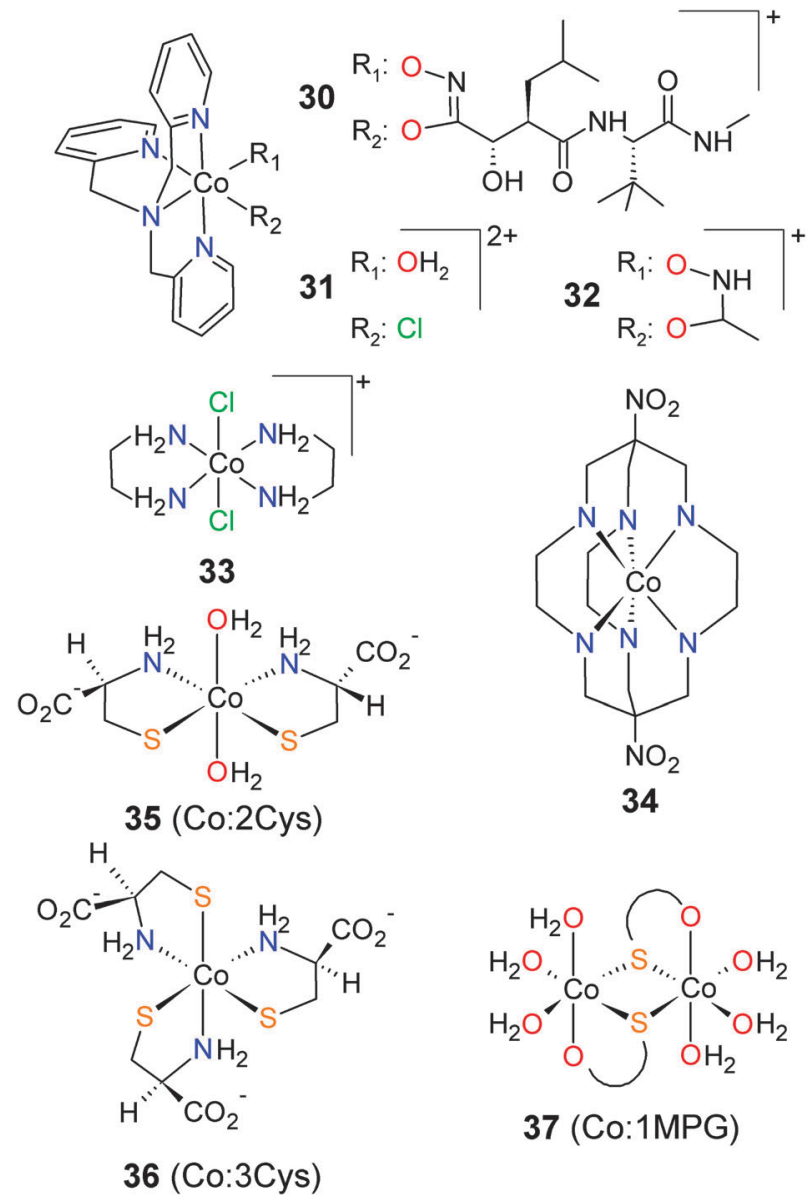

Fig. 14 Chemical structures of the cobalt-tpa marimastat complex. $[\mathrm{Co}(\mathrm{III})(\mathrm{mmst}) \mathrm{tpa}]^{+}$(mmst $=$marimastat, $\mathrm{tpa}=$ tris(methylpyridyl)amine) $(30)$, $\left[\mathrm{Co}(\mathrm{(II}) \mathrm{Cl}\left(\mathrm{H}_{2} \mathrm{O}\right) \mathrm{tpa}\right]^{2+}(31)$, [Co(aha-H)(tpa)]PF 6 (32, aha = acetohydroxamate), trans$\left[\mathrm{CoCl}_{2}(\mathrm{en})_{2}\right] \mathrm{Cl}(33)$, and of the diNOsar complex cobalt-1,8-dinitro-3,6,10,13,16,19hexaazabicyclo[6.6.6]eicosane (34, diNOsar = dinitrosarcophagine). In the lower part the Co-Cys complexes trans( $N, S)$-bis(cysteinato)diaquacobalt(III) (35, Co:2Cys) and one possible diastereoisomer of tris(cysteinato)cobalt(III) (36, Co:3Cys), and one possible structure of bis( $N$-(2-mercaptopropionyl)glycinato)triaquacobalt(II) (37, Co:1MPG).

assigned to a $1 \mathrm{~s} \rightarrow 3 \mathrm{~d}$ transition, was observable for many of the Co(III) complexes but none for $\mathrm{Co}(\mathrm{II}) \cdot{ }^{150,151}$ The ability to use XANES to quantify the ratio of $\mathrm{Co}(\mathrm{II})$ : $\mathrm{Co}(\mathrm{III})$ oxidation states in a mixture of unknown composition was tested. ${ }^{151}$ Aqueous solutions of known ratios of $\mathrm{Co}(\mathrm{II}) \mathrm{Cl}_{2}:\left[\mathrm{Co}(\mathrm{III})\left(\mathrm{NH}_{3}\right)_{6}\right] \mathrm{Cl}_{3}$ and $\mathrm{Co}(\mathrm{II}) \mathrm{Cl}_{2}: 31 \mathrm{Co}(\mathrm{III})$ (Fig. 14) were investigated according to their changes in energy positions and peak heights. With increasing $\mathrm{Co}(\mathrm{III})$ content in the aqueous solutions the maximum at approx. $7720 \mathrm{eV}$ decreased and the edge energy shifted toward higher energies. The relationship between the edge maximum to post edge minimum ratio $a / b$ in the XANES spectra and the proportion of $\mathrm{Co}(\mathrm{II})$ : $\mathrm{Co}$ (III) appeared to be parabolic. The determination of the $\mathrm{Co}(\mathrm{II})$ : $\mathrm{Co}$ (III) ratios in unknown mixtures through XANES was stated as feasible, as long as ligand exchange reactions in the $\mathrm{Co}$ (III) state are slow relative to reduction to $\mathrm{Co}(\mathrm{II}){ }^{151}$

6.1.2. Cell lines treated with cobalt compounds. The XANES spectra collected on A2780 human ovarian carcinoma 
cells treated with $\mathrm{Na}\left[\mathrm{Co}(\mathrm{II})(\mathrm{acac})_{3}\right]$ and $\left[\mathrm{Co}(\mathrm{III})(\mathrm{acac})_{3}\right]$ varied greatly from the solution spectra of the same compounds. ${ }^{150}$ After $24 \mathrm{~h}$ of incubation the XANES spectra of both compounds became nearly identical, and displayed similarities in the edge and post-edge minimum to the spectrum of the model compound 36 Co:3Cys (Fig. 14). ${ }^{150}$ Therefore, the coordination to intracellular sulfur ligands with an oxidation state of +3 appeared to be most reasonable. The solid state K-edge spectrum of the Co(III) complex 34 (Fig. 14) showed marginal differences to the solution spectra of $\mathbf{3 4}$ and to spectra collected from cells treated with $\mathbf{3 4}$, which is consistent with the high stability of cryptand cobalt complexes. ${ }^{150,152}$

6.1.3. Cobalt compounds in the presence of ascorbate, cysteine and glutathione. Detailed knowledge of the behaviour of Co in the presence of reducing agents and the binding of Co to GSH and Cys is important because: (i) it gives valuable hints towards the design for scavengers of Co contaminants and (ii) it gives important implications for the further development of Co containing metal-based therapeutics and their biochemical impact on the cell metabolism. The Co(III) compounds 31, 32, 33 (Fig. 14), and $\left[\mathrm{Co}(\mathrm{III})\left(\mathrm{NH}_{3}\right)_{6}\right] \mathrm{Cl}_{3}$ were investigated in aqueous solution with Co K-edge XANES. ${ }^{151}$ The changes in the spectra after addition of the reducing agents ascorbate (4-fold excess) and Cys were monitored over a time span of 2 h. ${ }^{151}$ The compounds 32 and $\left[\mathrm{Co}\left(\mathrm{NH}_{3}\right)_{6}\right] \mathrm{Cl}_{3}$ showed no changes in the spectral features after the addition of the reducing agents. The complex 33 showed a strong change in the position of the main absorption peak by $-7 \mathrm{eV}$ to lower energies and a shoulder at higher energies became apparent. Over a time period of $2 \mathrm{~h}$ the height of the edge peak further increased and the post edge shoulder became more prominent. After addition of ascorbate (4-fold excess) to a 31 (Fig. 14) containing solution an immediate shift of the absorption maximum by $-4 \mathrm{eV}$ and the diminishing of the pre- and post-edge shoulder occurred. The height of the maximum also increased immediately but stayed constant over time. Both results are clear evidence for the reduction to $\mathrm{Co}(\mathrm{II}){ }^{151}$

Bresson and coworkers studied the toxicity of cobalt toward HaCaT keratinocyte cells. ${ }^{153-158}$ Co K-edge XANES and EXAFS in combination with molecular dynamics (MD) calculations gave an insight into the binding behaviour of $\mathrm{Co}(\mathrm{II}) \mathrm{Cl}_{2}$ to biologically important thiol containing molecules. ${ }^{153-155}$ Cobalt model complexes were synthesized with the ligands Cys and $\mathrm{N}$-(2mercaptopropionyl)glycine (MPG), a synthetic analogue of the right hand portion of GSH. ${ }^{153}$ The complexes Co:2Cys (35, Fig. 14), Co:3Cys (36, Fig. 14) and Co:1MPG (37, Fig. 14) were measured in aqueous solutions at the Co K-edge, resulting in Co(II) and Co(III) XANES spectra showing the same features as described in the paragraph before in the studies of Bonnitcha and Hall. ${ }^{150,151} 35$ Co:2Cys and 36 Co:3Cys were identified to be in the $\mathrm{Co}$ (III) oxidation state, $37 \mathrm{Co:} 1 \mathrm{MPG}$ to be $\mathrm{Co}$ (II) upon comparison of the pre-edge positions. ${ }^{153}$ The oxidation states were dependent on the $\mathrm{pH}$ of the solutions ( $\mathrm{pH} 11$ for 35 Co:2Cys and 36 Co:3Cys, and pH 7 for 37 Co:1MPG). ${ }^{155}$ The EXAFS analysis of these compounds confirmed the proposed coordination of 2 Cys to 35 Co:2Cys and 3 Cys to $36 \mathrm{Co:3Cys} \mathrm{in}$ the Co(III) state (Fig. 14), respectively. ${ }^{153}$ In the case of 37

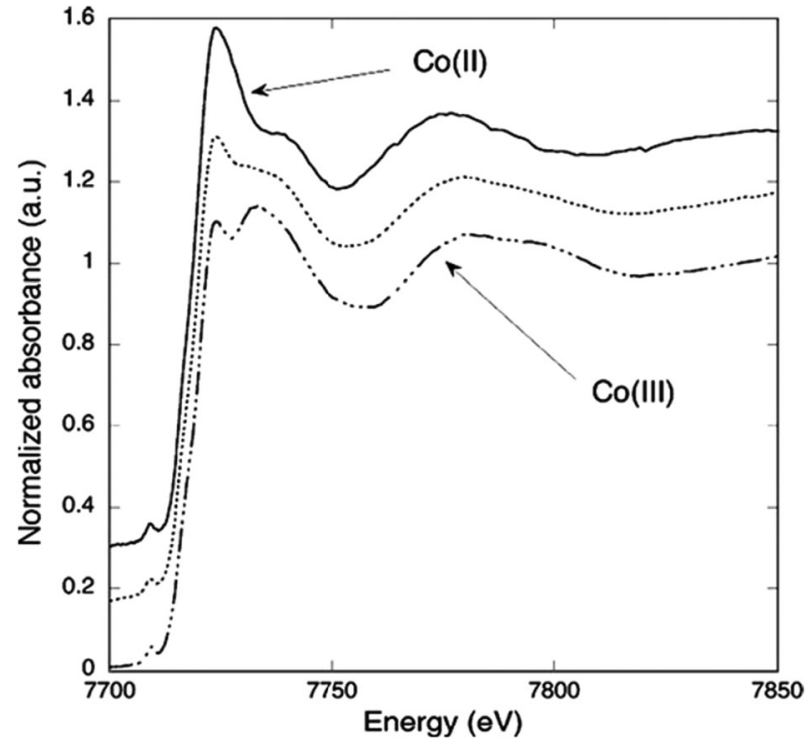

Fig. 15 XANES in situ monitoring of the oxidation of $38 \mathrm{Co}(11): 3$ Cys to 36 $\mathrm{Co}(\mathrm{II}): 3 \mathrm{Cys}$ at the Co K-edge. An intermediate mixture of $\mathrm{Co}(I)$ and $\mathrm{Co}(\mathrm{II})$ is represented by the middle dotted spectrum. Reprinted (adapted) with permission from C. Bresson, R. Spezia, S. Esnouf, P. L. Solari, S. Coantic, and C. D. Auwer, New J. Chem., 2007, 31, 1789-1797. Copyright 2007 Royal Society of Chemistry.

Co:1MPG a dinuclear cobalt compound bridged through the two sulfur atoms of the bidentate MPG ligands was the structure that best fitted the EXAFS data (Fig. 14). In a subsequent publication $^{155}$ the structures of tris(cysteinato)cobalt(II) (38, $\mathrm{Co}(\mathrm{II}): 3 \mathrm{Cys})$ and $36 \mathrm{Co}(\mathrm{III}): 3 \mathrm{Cys}$ were optimized through MD calculations $^{156}$ and used as structural models for the EXAFS analysis. ${ }^{155}$ EXAFS analysis of $36 \mathrm{Co}(\mathrm{III}): 3 \mathrm{Cys}$ with MD calculated and X-ray diffraction structural data gave the same results. ${ }^{155}$ In situ XANES measurements were used to follow the oxidation of $38 \mathrm{Co}$ (II):3Cys to $36 \mathrm{Co}(\mathrm{III})$ :3Cys (see Fig. 15), resulting in the progressive changes in the edge features toward an edge shape typical for a Co(III) species, visible through a decrease in the edge height and the development of a double-peaked edge shape. ${ }^{155}$

\section{Limitations of XAS and micro-SXRF}

In XANES and EXAFS, there is a need to acquire data for an extensive range of solid samples for modelling purposes. If the concentration of the element of interest is not high enough XAS is limited to the XANES regime and/or the resulting spectra are very noisy. The processing and fitting of the EXAFS data is non-trivial, and it is hard to distinguish between elements of nearly the same atomic number $Z$, as it is the case with $\mathrm{S}$ and $\mathrm{Cl}$, and $\mathrm{O}$ and $\mathrm{N}$. Like other spectroscopic techniques XAS probes only the average coordination sphere of the metals in a particular biological system, and much information is lost on the minor species present in the sample. In SXRF, physical fixation of the cell samples can lead to elemental rearrangement and loss of information. Sometimes, the data are limited by biologically relevant concentrations of the compounds in the biological systems, and higher dosages are needed to see the elements in the systems. 


\section{Conclusion}

XAS has proven to be a valuable tool for the investigation of the anti-cancer metals $\mathrm{Pt}, \mathrm{Ru}, \mathrm{Ga}, \mathrm{Au}$ and $\mathrm{Co}$ in biological environments. The near edge structure (XANES) provides information about the oxidation state, the electronic structure of the absorberligand environment and the coordination motif, while the extended fine structure (EXAFS) gives information about the amount, the type and the distance of the next neighbouring atoms up to a distance of about $4 \AA$. In the presence of the reducing agents ascorbate, $\mathrm{GSH}$ and/or Cys the reduction of $\mathrm{Ru}(\mathrm{III})$ to $\mathrm{Ru}$ (II), $\mathrm{Pt}$ (IV) to $\mathrm{Pt}($ II) and $\mathrm{Co}$ (III) to $\mathrm{Co}$ (II) was investigated by means of XANES spectroscopy. For Pt(Iv)/Pt(II) and $\mathrm{Co}$ (III)/Co(II) a method was presented to determine the ratio of these oxidation states in samples of unknown composition. This method was also applied to follow the reduction of metal based drugs in tissue and cell samples and to test the drug stability under physiological conditions. XAS is one of the few methods that allow the monitoring of exchange reactions of atoms at the absorber, like $\mathrm{O} / \mathrm{N}$ for $\mathrm{Cl} / \mathrm{S}$ or vice-versa, and the accompanying possible changes in the oxidation state. This fact was used in interaction studies of the metal based drugs with possible transport proteins in vivo like HSA, BSA and apoTf and to test their stability in solutions. The stability of platinum drugs in infusion solution was tested and the proposed biochemical pathways of $\mathrm{Ru}, \mathrm{Au}$ and $\mathrm{Ga}$ complexes were studied. Theoretical structural models optimized with DFT calculations have shown to be valuable tools for the analysis of XAS spectra and to identify the main chemical constitution of the element in an unknown sample or where detailed X-ray diffraction data are missing. This approach was used to obtain insight into the photo-chemistry of $\mathrm{Ru}$-bipyridine complexes and the activation mechanism of thiophenolate containing $\mathrm{Ru}$-arene complexes. Micro-SXRF studies ranging from several $\mu \mathrm{m}^{2}$ spotsize to the subcellular level have been undertaken on tissues derived from Pt, Ru and Ga treated mice and on cell lines treated with Pt and $\mathrm{Ru}$ anti-cancer agents. The transport into and within cells, the main leaving ligands and the major site of action as well as the penetration into the tissue and the correlation with other biologically important elements can be monitored. Micro-XAS allows the additional elucidation of the oxidation state and coordination at micro-metric spatial resolution in the sample.

In conclusion it can be said that the synchrotron radiation spectroscopic techniques presented here will play a vital role in medicinal chemistry in the future. With the approach of the fourth generation of synchrotron radiation facilities and their improved and more sensitive instrumentation, investigations in the sub- $\mu \mathrm{m}$ range at physiological concentrations will be possible at a high level of spectroscopic details. Examination methods like X-ray tomography will reduce the need for detrimental fixation and sectioning of tissue samples. The combination of micro-XAS and micro-SXRF will allow for the simultaneous investigation of the metal distribution and its metabolism. The further progress in the theory of XAS and the theoretical calculation of XAS spectra from artificially constructed structures will minimize the need for extensive collection of model compounds for analysis.

\section{Abbreviations}

\begin{tabular}{|c|c|}
\hline $4 \mathrm{AP}$ & 4-aminopyridine \\
\hline acac & acetylacetonate \\
\hline aha & acetohydroxamate \\
\hline apoTf & apo-transferrin \\
\hline $\mathrm{BN}$ & boron nitride \\
\hline bpy & 2,2'-bipyridine \\
\hline Brpyr & 3-bromopyridine \\
\hline BSA & bovine serum albumin \\
\hline CS buffer & citrate saline buffer \\
\hline Cys & cysteine \\
\hline DDTC & diethyl-dithiocarbamate \\
\hline DFT & density functional theory \\
\hline diNOsar & $\begin{array}{l}\text { 1,8-dinitro-3,6,10,13,16,19-hexaazabicyclo- } \\
\text { [6.6.6]-eicosane }\end{array}$ \\
\hline en & ethylenediamine \\
\hline $\mathrm{eV}$ & electron volt \\
\hline EXAFS & extended X-ray absorption fine structure \\
\hline FT & Fourier transform \\
\hline GSH & glutathione \\
\hline HOMO & highest occupied molecular orbital \\
\hline HSA & human serum albumin \\
\hline HSQC-NMR & $\begin{array}{l}\text { heteronuclear single quantum coherence } \\
\text { nuclear magnetic resonance }\end{array}$ \\
\hline LUMO & lowest unoccupied molecular orbital \\
\hline MD & molecular dynamics \\
\hline micro-SRIXE & $\begin{array}{l}\text { micro-synchrotron radiation induced X-ray } \\
\text { emission }\end{array}$ \\
\hline micro-XAS & micro-X-ray absorption spectroscopy \\
\hline $\begin{array}{l}\text { micro-SXRF } \\
\text { mmst }\end{array}$ & $\begin{array}{l}\text { micro-synchrotron based X-ray fluorescence } \\
\text { marimastat }\end{array}$ \\
\hline MPG & $N$-(2-mercaptopropionyl)glycine \\
\hline NBA & $n$-butylamine \\
\hline OAc & acetate \\
\hline $\mathrm{OAcBr}$ & bromacetato \\
\hline PBS & phosphate buffered saline \\
\hline pta & $\begin{array}{l}\text { 1,3,5-triaza-7-phosphatricyclo- } \\
\text { [3.3.1.1]decanephosphine }\end{array}$ \\
\hline py & pyridine \\
\hline RAPTA & ruthenium arene pta \\
\hline Sec & selenocysteine \\
\hline $\mathrm{SO}_{2} \mathrm{R}^{-}$ & sulfinate \\
\hline $\mathrm{SOR}^{-}$ & sulfenate \\
\hline $\mathrm{SR}^{-}$ & thiolate \\
\hline tagl & tetraacetylglucose \\
\hline Tf & transferrin \\
\hline tpa & tris(methylpyridyl)amine \\
\hline TrxR & thioredoxin reductase \\
\hline XANES & $\mathrm{X}$-ray absorption near edge structure \\
\hline XAS & X-ray absorption spectroscopy \\
\hline
\end{tabular}

\section{Acknowledgements}

The research was funded by the Austrian Science Fund (FWF): P23711-N19. This research was also funded by a short-term 
grant abroad (KWA) of the University of Vienna (call 15.10.2011). The results reported in this work are based on experiments carried out at synchrotron radiation facilities. A.A.H. and A.R. are grateful for the support through Diamond Light Source (SP1640, SP6303), the European Synchrotron Radiation Facility (MD-514, MD-678), the Angströmquelle Karlsruhe (OTH-88), and the Deutsche Elektronensynchrotron.

\section{References}

1 B. Rosenberg, L. Vancamp and T. Krigas, Nature, 1965, 205, 698-699.

2 M. A. Jakupec, M. Galanski, V. B. Arion, C. G. Hartinger and B. K. Keppler, Dalton Trans., 2008, 183-194.

3 B. Desoize, Anticancer Res., 2004, 24, 1529-1544.

4 S. H. van Rijt and P. J. Sadler, Drug Discovery Today, 2009, 14, 1089-1097.

5 N. Graf and S. J. Lippard, Adv. Drug Delivery Rev., 2012, 64, 993-1004.

6 U. Jungwirth, C. R. Kowol, B. K. Keppler, C. G. Hartinger, W. Berger and P. Heffeter, Antioxid. Redox Signaling, 2011, 15, 1085-1128.

7 S. P. Best and M. H. Cheah, Radiat. Phys. Chem., 2010, 79, 185-194.

8 R. W. Strange and M. C. Feiters, Curr. Opin. Struct. Biol., 2008, 18, 609-616.

9 J. Yano and V. K. Yachandra, Photosynth. Res., 2009, 102, 241-254.

10 G. N. George, Curr. Opin. Struct. Biol., 1993, 3, 780-784.

11 B. Akabayov, C. J. Doonan, I. J. Pickering, G. N. George and I. Sagi, J. Synchrotron Radiat., 2005, 12, 392-401.

12 I. Nicolis, E. Curis, P. Deschamps and S. Bénazeth, J. Synchrotron Radiat., 2003, 10, 96-102.

13 M. Groessl and P. J. Dyson, Curr. Top. Med. Chem., 2011, 11, 2632-2646.

14 R. Ortega, A. Carmona, I. Llorens and P. L. Solari, J. Anal. At. Spectrom., 2012, 27, 2054-2065.

15 R. Ortega, Nucl. Instrum. Methods Phys. Res., Sect. B, 2005, 231, 218-223.

16 R. Ortega, J. Anal. At. Spectrom., 2010, 26, 23-29.

17 S. Majumdar, J. R. Peralta-Videa, H. Castillo-Michel, J. Hong, C. M. Rico and J. L. Gardea-Torresdey, Anal. Chim. Acta, 2012, 755, 1-16.

18 G. Bunker, Introduction to XAFS: A Practical Guide to X-ray Absorption Fine Structure Spectroscopy, Cambridge University Press, Cambridge, 1st edn, 2010.

19 S. D. Kelly, D. Hesterberg and B. Ravel, Methods of Soil Analysis. Part 5. Mineralogical Methods., American Society of Agronomy, Madison, 2008, vol. 5, pp. 387-463.

20 D. C. Koningsberger, B. L. Mojet, G. E. Van Dorssen and D. E. Ramaker, Top. Catal., 2000, 10, 143-155.

21 B. Ravel and M. Newville, J. Synchrotron Radiat., 2005, 12, 537-541.

22 F. de Groot and A. Kotani, Core Level Spectroscopy of Solids, Crc Pr Inc., 2008.
23 J. Stöhr, NEXAFS Spectroscopy, Springer, 1st edn 1992, Corr. 2nd printing 2003, 1992.

24 J. E. Penner-Hahn, Coord. Chem. Rev., 1999, 190, 1101-1123.

25 F. de Groot, Chem. Rev., 2001, 101, 1779-1808.

26 J. J. Rehr and R. C. Albers, Rev. Mod. Phys., 2000, 72, 621-654.

27 A. L. Ankudinov, B. Ravel, J. J. Rehr and S. D. Conradson, Phys. Rev. B: Condens. Matter Mater. Phys., 1998, 58, 7565-7576.

28 F. W. Lytle, J. Synchrotron Radiat., 1999, 6, 123-134.

29 R. S. von Bordwehr, Ann. Phys., 1989, 14, 377-465.

30 P. Ilinski, B. Lai, Z. Cai, W. Yun, D. Legnini, T. Talarico, M. Cholewa, L. K. Webster, G. B. Deacon, S. Rainone, D. R. Phillips and A. P. J. Stampfl, Cancer Res., 2003, 63, 1776-1779.

31 R. Ortega, P. Moretto, A. Fajac, J. Benard, Y. Llabador and M. Simonoff, Cell. Mol. Biol. (Noisy-le-grand), 1996, 42, 77-88.

32 J. E. Penner-Hahn, Coord. Chem. Rev., 2005, 249, 161-177.

33 S. J. Lippard and J. M. Berg, Principles of bioinorganic chemistry, University Science Books, 1994.

34 B. D. Evans, K. S. Raju, A. H. Calvert, S. J. Harland and E. Wiltshaw, Cancer Treat. Rep., 1983, 67, 997-1000.

35 Y. Kidani and K. Inagaki, U.S. Pat. 4169846, 1979.

36 T. W. Hambley, Dalton Trans., 2007, 4929-4937.

37 E. Reisner, V. B. Arion, B. K. Keppler and A. J. L. Pombeiro, Inorg. Chim. Acta, 2008, 361, 1569-1583.

38 O. Shiratori, H. Kanai, Y. Uchida, Y. Takeda, T. Totani and K. Sato, Recent Advances in Chemotherapy, University of Tokyo Press, Tokyo, 1985, pp. 635-636.

39 N. J. Wheate, S. Walker, G. E. Craig and R. Oun, Dalton Trans., 2010, 39, 8113-8127.

40 F. Muggia, Gynecol. Oncol., 2009, 112, 275-281.

41 L. M. Pasetto, M. R. D’Andrea, A. A. Brandes, E. Rossi and S. Monfardini, Crit. Rev. Oncol. Hematol., 2006, 60, 59-75.

42 B. Desoize and C. Madoulet, Crit. Rev. Oncol. Hematol., 2002, 42, 317-325.

43 L. Kelland, Nat. Rev. Cancer, 2007, 7, 573-584.

44 H. Zorbas and B. K. Keppler, ChemBioChem, 2005, 6, 1157-1166.

45 M. D. Hall and T. W. Hambley, Coord. Chem. Rev., 2002, 232, 49-67.

46 M. D. Hall, H. R. Mellor, R. Callaghan and T. W. Hambley, J. Med. Chem., 2007, 50, 3403-3411.

47 P. Gramatica, E. Papa, M. Luini, E. Monti, M. B. Gariboldi, M. Ravera, E. Gabano, L. Gaviglio and D. Osella, JBIC, J. Biol. Inorg. Chem., 2010, 15, 1157-1169.

48 S. van Zutphen and J. Reedijk, Coord. Chem. Rev., 2005, 249, 2845-2853.

49 J. Moretto, B. Chauffert, F. Ghiringhelli, J. R. AldrichWright and F. Bouyer, Invest. New Drugs, 2011, 29, 1164-1176.

50 J. Ruiz, V. Rodríguez, N. Cutillas, A. Espinosa and M. J. Hannon, J. Inorg. Biochem., 2011, 105, 525-531.

51 C. Sanchez-Cano and M. J. Hannon, Dalton Trans., 2009, 10702-10711. 
52 C. T. Dillon, Aust. J. Chem., 2012, 65, 204-217.

53 B.-K. Teo, P. Eisenberger, J. Reed, J. K. Barton and S. J. Lippard, J. Am. Chem. Soc., 1978, 100, 3225-3227.

54 M. D. Hall, G. J. Foran, M. Zhang, P. J. Beale and T. W. Hambley, J. Am. Chem. Soc., 2003, 125, 7524-7525.

55 H. L. Daly, M. D. Hall, T. W. Failes, M. Zhang, G. J. Foran and T. W. Hambley, Aust. J. Chem., 2011, 64, 273-278.

56 M. D. Hall, H. L. Daly, J. Z. Zhang, M. Zhang, R. A. Alderden, D. Pursche, G. J. Foran and T. W. Hambley, Metallomics, 2012, 4, 568-575.

57 A. Nemirovski, I. Vinograd, K. Takrouri, A. Mijovilovich, A. Rompel and D. Gibson, Chem. Commun., 2010, 46, 1842-1844.

58 M. Obata, M. Harada, H. Ohi, S. Hirohara, M. Gottchaldt and S. Yano, Chem. Pharm. Bull., 2009, 57, 1107-1109.

59 K. Provost, D. Bouvet-Muller, S. Crauste-Manciet, J. Moscovici, L. Olivi, G. Vlaic and A. Michalowicz, Biochimie, 2009, 91, 1301-1306.

60 E. Curis, K. Provost, I. Nicolis, D. Bouvet, S. Bénazeth, S. Crauste-Manciet, F. Brion and D. Brossard, New J. Chem., 2000, 24, 1003-1008.

61 E. Curis, K. Provost, D. Bouvet, I. Nicolis, S. CrausteManciet, D. Brossard and S. Bénazeth, J. Synchrotron Radiat., 2001, 8, 716-718.

62 E. C. Beret, K. Provost, D. Müller and E. S. Marcos, J. Phys. Chem. B, 2009, 113, 12343-12352.

63 D. Bouvet, A. Michalowicz, S. Crauste-Manciet, D. Brossard and K. Provost, Inorg. Chem., 2006, 45, 3393-3398.

64 D. Bouvet, A. Michalowicz, S. Crauste-Manciet, E. Curis, I. Nicolis, L. Olivi, G. Vlaic, D. Brossard and K. Provost, J. Synchrotron Radiat., 2006, 13, 477-483.

65 M. D. Hall, C. T. Dillon, M. Zhang, P. Beale, Z. Cai, B. Lai, A. P. J. Stampfl and T. W. Hambley, JBIC, J. Biol. Inorg. Chem., 2003, 8, 726-732.

66 M. D. Hall, R. A. Alderden, M. Zhang, P. J. Beale, Z. Cai, B. Lai, A. P. J. Stampfl and T. W. Hambley, J. Struct. Biol., 2006, 155, 38-44.

67 K. J. Davis, J. A. Carrall, B. Lai, J. R. Aldrich-Wright, S. F. Ralph and C. T. Dillon, Dalton Trans., 2012, 41, 9417-9426.

68 J. Z. Zhang, N. S. Bryce, A. Lanzirotti, C. K. J. Chen, D. Paterson, M. D. de Jonge, D. L. Howard and T. W. Hambley, Metallomics, 2012, 4, 1209-1217.

69 C. G. Hartinger, S. Zorbas-Seifried, M. A. Jakupec, B. Kynast, H. Zorbas and B. K. Keppler, J. Inorg. Biochem., 2006, 100, 891-904.

70 C. G. Hartinger, M. A. Jakupec, S. Zorbas-Seifried, M. Groessl, A. Egger, W. Berger, H. Zorbas, P. J. Dyson and B. K. Keppler, Chem. Biodiversity, 2008, 5, 2140-2155.

71 P. Heffeter, M. Pongratz, E. Steiner, P. Chiba, M. A. Jakupec, L. Elbling, B. Marian, W. Körner, F. Sevelda, M. Micksche, B. K. Keppler and W. Berger, J. Pharmacol. Exp. Ther., 2005, 312, 281-289.

72 E. Alessio, G. Mestroni, A. Bergamo and G. Sava, Curr. Top. Med. Chem., 2004, 4, 1525-1535.

73 K.-G. Lipponer, E. Vogel and B. K. Keppler, Met.-Based Drugs, 1996, 3, 243-260.
74 W. Peti, T. Pieper, M. Sommer, B. K. Keppler and G. Giester, Eur. J. Inorg. Chem., 1999, 1551-1555.

75 P. Heffeter, K. Böck, B. Atil, M. Reza Hoda, W. Körner, C. Bartel, U. Jungwirth, B. Keppler, M. Micksche, W. Berger and G. Koellensperger, JBIC, J. Biol. Inorg. Chem., 2010, 15, 737-748.

76 G. Mestroni, E. Alessio and G. Sava, International Patent PCT C 07F 15/00, A61K 31/28 WO 98/00431, 1998.

77 A. Bergamo, R. Gagliardi, V. Scarcia, A. Furlani, E. Alessio, G. Mestroni and G. Sava, J. Pharmacol. Exp. Ther., 1999, 289, 559-564.

78 G. Sava, S. Zorzet, C. Turrin, F. Vita, M. Soranzo, G. Zabucchi, M. Cocchietto, A. Bergamo, S. DiGiovine, G. Pezzoni, L. Sartor and S. Garbisa, Clin. Cancer Res., 2003, 9, 1898-1905.

79 M. A. Jakupec, E. Reisner, A. Eichinger, M. Pongratz, V. B. Arion, M. Galanski, C. G. Hartinger and B. K. Keppler, J. Med. Chem., 2005, 48, 2831-2837.

80 N. Cetinbas, M. I. Webb, J. A. Dubland and C. J. Walsby, JBIC, J. Biol. Inorg. Chem., 2009, 15, 131-145.

81 J. B. Aitken, A. Levina and P. A. Lay, Curr. Top. Med. Chem., 2011, 11, 553-571.

82 A. Levina, A. Mitra and P. A. Lay, Metallomics, 2009, 1, 458-470.

83 A. Bergamo and G. Sava, Dalton Trans., 2007, 1267-1272.

84 F. Frausin, V. Scarcia, M. Cocchietto, A. Furlani, B. Serli, E. Alessio and G. Sava, J. Pharmacol. Exp. Ther., 2005, 313, 227-233.

85 B. Gava, S. Zorzet, P. Spessotto, M. Cocchietto and G. Sava, J. Pharmacol. Exp. Ther., 2006, 317, 284-291.

86 S. Zorzet, A. Bergamo, M. Cocchietto, A. Sorc, B. Gava, E. Alessio, E. Iengo and G. Sava, J. Pharmacol. Exp. Ther., 2000, 295, 927-933.

87 A. F. A. Peacock and P. J. Sadler, Chem.-Asian J., 2008, 3, 1890-1899.

88 W. H. Ang and P. J. Dyson, Eur. J. Inorg. Chem., 2006, 4003-4018.

89 R. E. Aird, J. Cummings, A. A. Ritchie, M. Muir, R. E. Morris, H. Chen, P. J. Sadler and D. I. Jodrell, Br. J. Cancer, 2002, 86, 1652-1657.

90 F. Wang, A. Habtemariam, E. P. L. van der Geer, R. Fernández, M. Melchart, R. J. Deeth, R. Aird, S. Guichard, F. P. A. Fabbiani, P. Lozano-Casal, I. D. H. Oswald, D. I. Jodrell, S. Parsons and P. J. Sadler, Proc. Natl. Acad. Sci. U. S. A., 2005, 102, 18269-18274.

91 H. Petzold, J. Xu and P. J. Sadler, Angew. Chem., Int. Ed., 2008, 47, 3008-3011.

92 T. Sriskandakumar, H. Petzold, P. C. A. Bruijnincx, A. Habtemariam, P. J. Sadler and P. Kennepohl, J. Am. Chem. Soc., 2009, 131, 13355-13361.

93 C. S. Allardyce, P. J. Dyson, D. J. Ellis and S. L. Heath, Chem. Commun., 2001, 1396-1397.

94 P. J. Dyson, Chimia, 2007, 61, 698-703.

95 S. Betanzos-Lara, L. Salassa, A. Habtemariam, O. Novakova, A. M. Pizarro, G. J. Clarkson, B. Liskova, V. Brabec and P. J. Sadler, Organometallics, 2012, 31, 3466-3479. 
96 S. Betanzos-Lara, O. Novakova, R. J. Deeth, A. M. Pizarro, G. J. Clarkson, B. Liskova, V. Brabec, P. J. Sadler and A. Habtemariam, JBIC, J. Biol. Inorg. Chem., 2012, 17, 1033-1051.

97 L. Zayat, C. Calero, P. Alborés, L. Baraldo and R. Etchenique, J. Am. Chem. Soc., 2003, 125, 882-883.

98 L. Zayat, M. Salierno and R. Etchenique, Inorg. Chem., 2006, 45, 1728-1731.

99 L. Salassa, C. Garino, G. Salassa, C. Nervi, R. Gobetto, C. Lamberti, D. Gianolio, R. Bizzarri and P. J. Sadler, Inorg. Chem., 2009, 48, 1469-1481.

100 A. A. Hummer, P. Heffeter, W. Berger, M. Filipits, D. Batchelor, G. Büchel, M. A. Jakupec, B. K. Keppler and A. Rompel, J. Med. Chem., 2013, 56, 1182-1196.

101 T. V. Harris, R. K. Szilagyi and K. L. M. Holman, JBIC, J. Biol. Inorg. Chem., 2009, 14, 891-898.

102 B. K. Keppler, W. Rupp, U. M. Juhl, H. Endres, R. Niebl and W. Balzer, Inorg. Chem., 1987, 26, 4366-4370.

103 M. Liu, Z. J. Lim, Y. Y. Gwee, A. Levina and P. A. Lay, Angew. Chem., Int. Ed., 2010, 49, 1661-1664.

104 I. Ascone, L. Messori, A. Casini, C. Gabbiani, A. Balerna, F. Dell'Unto and A. C. Castellano, Inorg. Chem., 2008, 47, 8629-8634.

105 J. B. Aitken, S. Antony, C. M. Weekley, B. Lai, L. Spiccia and H. H. Harris, Metallomics, 2012, 4, 1051-1056.

106 L. Salassa, D. Gianolio, C. Garino, G. Salassa, E. Borfecchia, T. Ruiu, C. Nervi, R. Gobetto, R. Bizzarri, P. J. Sadler and C. Lamberti, J. Phys.: Conf. Ser., 2009, 190, 012141.

107 L. Salassa, E. Borfecchia, T. Ruiu, C. Garino, D. Gianolio, R. Gobetto, P. J. Sadler, M. Cammarata, M. Wulff and C. Lamberti, Inorg. Chem., 2010, 49, 11240-11248.

108 L. Salassa, T. Ruiu, C. Garino, A. M. Pizarro, F. Bardelli, D. Gianolio, A. Westendorf, P. J. Bednarski, C. Lamberti, R. Gobetto and P. J. Sadler, Organometallics, 2010, 29, 6703-6710.

109 T. E. Westre, P. Kennepohl, J. G. DeWitt, B. Hedman, K. O. Hodgson and E. I. Solomon, J. Am. Chem. Soc., 1997, 119, 6297-6314.

110 K. Getty, M. U. Delgado-Jaime and P. Kennepohl, Inorg. Chim. Acta, 2008, 361, 1059-1065.

111 M. J. Clarke, F. Zhu and D. R. Frasca, Chem. Rev., 1999, 99, 2511-2534.

112 C. R. Chitambar and Z. Zivkovic, Cancer Res., 1987, 47, 3929.

113 D. R. Richardson and P. Ponka, Biochim. Biophys. Acta, 1997, 1331, 1-40.

114 N. P. Davies, Y. S. Rahmanto, C. R. Chitambar and D. R. Richardson, J. Pharmacol. Exp. Ther., 2006, 317, 153.

115 A. A. Hummer, C. Bartel, V. B. Arion, M. A. Jakupec, W. Meyer-Klaucke, T. Geraki, P. D. Quinn, A. Mijovilovich, B. K. Keppler and A. Rompel, J. Med. Chem., 2012, 55, 5601-5613.

116 R. Bockman, M. Repo, R. Warrell, J. Pounds, G. Schidlovsky, B. Gordon and K. Jones, Proc. Natl. Acad. Sci. U. S. A., 1990, 87, 4149.

117 M. Korbas, E. Rokita, W. Meyer-Klaucke and J. Ryczek, JBIC, J. Biol. Inorg. Chem., 2004, 9, 67-76.
118 A. S. Thakor, J. Jokerst, C. Zavaleta, T. F. Massoud and S. S. Gambhir, Nano Lett., 2011, 11, 4029-4036.

119 C. F. Shaw, Chem. Rev., 1999, 99, 2589-2600.

120 E. R. T. Tiekink, Gold Bull., 2003, 36, 117-124.

121 S. J. Berners-Price and A. Filipovska, Metallomics, 2011, 3, 863-873.

122 C.-M. Che and R. W.-Y. Sun, Chem. Commun., 2011, 47, 9554-9560.

123 R. C. Elder and M. K. Eidsness, Chem. Rev., 1987, 87, 1027-1046.

124 A. Casini and L. Messori, Curr. Top. Med. Chem., 2011, 11, 2647-2660.

125 S. Nobili, E. Mini, I. Landini, C. Gabbiani, A. Casini and L. Messori, Med. Res. Rev., 2010, 30, 550-580.

126 C. Gabbiani, A. Casini and L. Messori, Gold Bull., 2006, 40, 73-81.

127 A. Casini, C. Hartinger, C. Gabbiani, E. Mini, P. J. Dyson, B. K. Keppler and L. Messori, J. Inorg. Biochem., 2008, 102, 564-575.

128 A. Molter and F. Mohr, Coord. Chem. Rev., 2010, 254, 19-45.

129 F. Caruso, R. Villa, M. Rossi, C. Pettinari, F. Paduano, M. Pennati, M. G. Daidone and N. Zaffaroni, Biochem. Pharmacol., 2007, 73, 773-781.

130 Y. Omata, M. Folan, M. Shaw, R. L. Messer, P. E. Lockwood, D. Hobbs, S. Bouillaguet, H. Sano, J. B. Lewis and J. C. Wataha, Toxicol. In Vitro, 2006, 20, 882-890.

131 M. Coronnello, E. Mini, B. Caciagli, M. A. Cinellu, A. Bindoli, C. Gabbiani and L. Messori, J. Med. Chem., 2005, 48, 6761-6765.

132 P. J. Barnard, M. V. Baker, S. J. Berners-Price and D. A. Day, J. Inorg. Biochem., 2004, 98, 1642-1647.

133 E. S. J. Arnér and A. Holmgren, Eur. J. Biochem., 2000, 267, 6102-6109.

134 L. Messori, A. Balerna, I. Ascone, C. Castellano, C. Gabbiani, A. Casini, C. Marchioni, G. Jaouen and A. C. Castellano, JBIC, J. Biol. Inorg. Chem., 2010, 16, 491-499.

135 G. Marcon, L. Messori, P. Orioli, M. A. Cinellu and G. Minghetti, Eur. J. Biochem., 2003, 270, 4655-4661.

136 A. Casini, M. A. Cinellu, G. Minghetti, C. Gabbiani, M. Coronnello, E. Mini and L. Messori, J. Med. Chem., 2006, 49, 5524-5531.

137 C. Gabbiani, A. Casini, L. Messori, A. Guerri, M. A. Cinellu, G. Minghetti, M. Corsini, C. Rosani, P. Zanello and M. Arca, Inorg. Chem., 2008, 47, 2368-2379.

138 M. A. Cinellu, L. Maiore, M. Manassero, A. Casini, M. Arca, H.-H. Fiebig, G. Kelter, E. Michelucci, G. Pieraccini, C. Gabbiani and L. Messori, ACS Med. Chem. Lett., 2010, 1, 336-339.

139 M. A. Soldatov, I. Ascone, A. C. Castellano, L. Messori, M. A. Cinellu, A. Balerna, A. V. Soldatov and G. E. Yalovega, J. Phys.: Conf. Ser., 2009, 190, 012210.

140 R. C. Elder, M. K. Eidsness, M. J. Heeg, K. G. Tepperman, C. F. Shaw and N. Schaeffer, Platinum, Gold, and Other Metal Chemotherapeutic Agents, American Chemical Society, 1983, vol. 209, pp. 385-400.

141 D. T. Hill, A. A. Isab, D. E. Griswold, M. J. DiMartino, E. D. Matz, A. L. Figueroa, J. E. Wawro, C. DeBrosse, 
W. M. Reiff, R. C. Elder, B. Jones, J. W. Webb and C. F. Shaw, Inorg. Chem., 2010, 49, 7663-7675.

142 D. C. Ware, P. J. Brothers, G. R. Clark, W. A. Denny, B. D. Palmer and W. R. Wilson, J. Chem. Soc., Dalton Trans., 2000, 925-932.

143 D. C. Ware, W. R. Wilson, W. A. Denny and C. E. F. Rickard, J. Chem. Soc., Chem. Commun., 1991, 1171-1173.

144 D. Ware, H. Palmer, F. Pruijn, R. Anderson, P. Brothers, W. Denny and W. Wilson, Anti-Cancer Drug Des., 1998, 13, 81-103.

145 D. C. Ware, B. D. Palmer, W. R. Wilson and W. A. Denny, J. Med. Chem., 1993, 36, 1839-1846.

146 T. Gianferrara, I. Bratsos and E. Alessio, Dalton Trans., 2009, 7588-7598.

147 M. Hidalgo and S. G. Eckhardt, J. Natl. Cancer Inst., 2001, 93, 178-193.

148 T. W. Failes, C. Cullinane, C. I. Diakos, N. Yamamoto, J. G. Lyons and T. W. Hambley, Chem.-Eur. J., 2007, 13, 2974-2982.

149 N. Johansson, M. Ahonen and V.-M. Kähäri, Cell. Mol. Life Sci., 2000, 57, 5-15.

150 P. D. Bonnitcha, M. D. Hall, C. K. Underwood, G. J. Foran, M. Zhang, P. J. Beale and T. W. Hambley, J. Inorg. Biochem., 2006, 100, 963-971.
151 M. D. Hall, C. K. Underwood, T. W. Failes, G. J. Foran and T. W. Hambley, Aust. J. Chem., 2007, 60, 180-183.

152 M. D. Hall, T. W. Failes, N. Yamamoto and T. W. Hambley, Dalton Trans., 2007, 3983-3990.

153 C. Bresson, S. Esnouf, C. Lamouroux, P. L. Solari and C. D. Auwer, New J. Chem., 2006, 30, 416-424.

154 C. Bresson, C. Lamouroux, C. Sandre, M. Tabarant, N. Gault, J. L. Poncy, J. L. Lefaix, C. Den Auwer, R. Spezia, M.-P. Gaigeot, E. Ansoborlo, S. Mounicou, A. Fraysse, G. Deves, T. Bacquart, H. Seznec, T. Pouthier, P. Moretto, R. Ortega, R. Lobinski and C. Moulin, Biochimie, 2006, 88, 1619-1629.

155 C. Bresson, R. Spezia, S. Esnouf, P. L. Solari, S. Coantic and C. D. Auwer, New J. Chem., 2007, 31, 1789-1797.

156 R. Spezia, C. Bresson, C. D. Auwer and M.-P. Gaigeot, J. Phys. Chem. B, 2008, 112, 6490-6499.

157 R. Ortega, C. Bresson, A. Fraysse, C. Sandre, G. Devès, C. Gombert, M. Tabarant, P. Bleuet, H. Seznec, A. Simionovici, P. Moretto and C. Moulin, Toxicol. Lett., 2009, 188, 26-32.

158 N. Gault, C. Sandre, J.-L. Poncy, C. Moulin, J.-L. Lefaix and C. Bresson, Toxicol. In Vitro, 2010, 24, 92-98. 